\title{
Conservation Status of the Family Orchidaceae in Spain Based on European, National, and Regional Catalogues of Protected Species
}

\author{
Daniel de la Torre Llorente \\ Biotechnology-Plant Biology Department, Higher Technical School of Agronomic, Food and Biosystems Engineering, \\ Universidad Politécnica de Madrid, 28140 Madrid, Spain
}

Correspondence should be addressed to Daniel de la Torre Llorente; daniel.delatorre@upm.es

Received 22 June 2017; Accepted 28 December 2017; Published 30 January 2018

Academic Editor: António Amorim

Copyright (C) 2018 Daniel de la Torre Llorente. This is an open access article distributed under the Creative Commons Attribution License, which permits unrestricted use, distribution, and reproduction in any medium, provided the original work is properly cited.

This report reviews the European, National, and Regional catalogues of protected species, focusing specifically on the Orchidaceae family to determine which species seem to be well-protected and where they are protected. Moreover, this examination highlights which species appear to be underprotected and therefore need to be included in some catalogues of protection or be catalogued under some category of protection. The national and regional catalogues that should be implemented are shown, as well as what species should be included within them. This report should be a helpful guideline for environmental policies about orchid's conservation in Spain, at least at the regional and national level. Around $76 \%$ of the Spanish orchid flora are listed with any figure of protection or included in any red list, either nationally (about $12-17 \%$ ) or regionally $(72 \%)$.

\section{Introduction}

The family Orchidaceae is widely represented in Europe, with 35 known genera, of which 25 are present in the Iberian Peninsula-26 including the Canary Islands-where the representation of this family is one of the most extensive ones, at least on an extratropical, equivalent level or only slightly lower than in other countries of the Mediterranean region. Taxonomic and floristic studies of this family in the Iberian Peninsula have been increasing slowly, though in a fragmented way over time. The first published quotes regarding the Orchidaceae family date back to $1861[1,2]$, and the first in-depth study of the family was conducted in 1887 [3]. Later, in 1930, a doctoral thesis examining the species in Spanish territory was published [4], but it was not until 1973 that a compendium comprising more or less all knowledge of Spanish orchids to date was published [5]. Since the 1960s, numerous French, Belgian, German, and English orchidologists have visited Spain and have extensively contributed, with the description of new taxa, to taxonomic and corological knowledge of this family. In addition, since
1970, herborization by numerous Spanish botanists has generated many studies, resulting in the development of abundant local, provincial, and regional catalogues of the Iberian territory, which contain new information concerning representatives of the Orchidaceae family, such as Granada $[6,7]$, Navarre [8], Portugal [9, 10], Albacete [11], Andalusia $[12,13]$, Balearic Islands $[14,15]$, Cuenca $[16,17]$, Extremadura $[18,19]$, Jaén [20], Burgos [21-23], Catalonia [24-26], Alicante [27, 28], Málaga [29], Almería [30], Galicia [31, 32], La Rioja [33], the Basque Country [34], Murcia [35], and Aragón [36]. The most updated and complete corological work that collects information on the distribution of Orchidaceae in the autonomous community of Madrid dates to 1994 [37]. Later works have helped to supplement such information [38].

Additional evidence of incipient interest in the Orchidaceae family is the publication of several European and Mediterranean orchid guidelines [39-46]. All this research work has generated an intense proliferation of names given to members of the Orchidaceae family in Spanish territories. However, recent works are helping to simplify the nomenclature complexity of existing synonymy for this family. These 
works include the entire family, certain subfamilies, tribes or subtribes [47-60], or more specific works at the level of certain genera like Serapias [61], Dactylorhiza [62, 63], Nigritella and Gymnadenia [64-66], Anacamptis, Orchis, and Neotinea [67-69], Limnorchis and Platanthera [70], Chamorchis and Traunsteinera [71], or Ophrys [72, 73].

The study of the taxa in this family, specifically its conservation and stability in landscapes, is essential for the stability of the vegetation and landscape [19]. Much of the representatives of the family Orchidaceae appear in areas with minimal processing and a certain environmental stability, although there may be human presence. This situation has facilitated the use of orchids as bioindicators in the environmental management of the territory in dehesas [74] and deciduous forests [75] and in the conservation of habitats.

\section{Material and Methods}

The nomenclature suggested by Flora iberica has been followed in this work for the family Orchidaceae [76].

The following catalogues and regulations have been checked.

At the European level, the following have been consulted:

(i) Habitats Directive [77]

(ii) Berne Convention [78].

At the national level, the following have been consulted:

(i) National Catalogue of Threatened Species (CNEA) [79] and successive modifications and updates that affect the Orchidaceae family [80-82]

(ii) Law on Natural Heritage and Biodiversity [83]

(iii) Red List of Spanish Vascular Flora [84] and successive modifications and updates:

(iv) 2008 Red List of Spanish Vascular Flora [85]

(v) 2010 Red List of Spanish Vascular Flora, updated with the data of the Addendum 2010 to the Atlas and Red Book of the Vascular Threatened Flora [86]

(vi) Atlas and Red Book of the Vascular Threatened Flora [86-89].

At the regional level, the following have been consulted:

(i) Plan of Recovery of Cypripedium calceolus L. in Aragón [90] - the only regional plan for recovery of orchids in Spain

(ii) Plans for recovery and conservation of certain wild species and habitats protected in Andalusia [91]

(iii) Red List of the Vascular Flora of Andalusia [92]

(iv) Red List of the Vascular Flora of CAPV (Comunidad Autónoma del País Vasco), thereafter Red List of the Basque Country [93].

Likewise, this study examined the seventeen corresponding regional catalogues (RC) of each of the seventeen autonomous Spanish communities:
(1) Andalusia $[94,95]$

(2) Aragón [96-98]

(3) Asturias [99]

(4) Balearic Islands [100]

(5) Basque Country [101-103]

(6) Canary Islands $[104,105]$

(7) Cantabria [106]

(8) Castilla-La Mancha $[107,108]$

(9) Castilla y León [109]

(10) Catalonia [110]

(11) Comunidad Valenciana [111]

(12) Extremadura [112]

(13) Galicia [113]

(14) La Rioja [114]

(15) Madrid [115]

(16) Murcia [116]

(17) Navarre [117].

The data obtained from the aforementioned catalogues were analysed, and the results of this analysis are presented in the Results of this report.

The taxa included in the CNEA were those species, subspecies, or populations of wild flora that require specific measures of protection. The category in which those taxa must be included is determined by considering threat factors facing the taxa throughout its natural distribution area inside the national territory, notwithstanding any potential mitigating or aggravating local circumstances of that threat [79]. As a rule, a species, subspecies, or populations of wild flora that require specific or special measures of protection and conservation must be included in regional catalogues. Besides, some regions include more specific criteria for their catalogues. For example, the $\mathrm{RC}$ of the Balearic Islands includes those taxa that require conservation measures because of their special interest or because the taxa are not included in the CNEA [100]; the RC of the Canary Islands includes those taxa that require specific measures of protection or that are interesting for Canarian ecosystems [105]; the RC of Extremadura, the $\mathrm{RC}$ of Galicia, and the RC of La Rioja include those taxa that require specific measures of protection attending to their rarity, singularity, representativeness, or exceptional nature [112-114]. The RC of Catalonia includes those taxa that are threatened in Catalonia and that require conservation measures according to their ecological and environmental values [110]. The RC of Castilla-La Mancha includes those taxa that are native to Castilla-La Mancha and maintain stable populations in the region, are subjected to threat factors, or are of special interest, thus requiring specific measures of protection [107]. The RC of Andalusia includes those taxa that deserve special attention and protection due to their scientific, ecological, or cultural value or due to their singularity, rarity, or degree of threat; it includes as well those taxa that are protected in different appendixes of international 
directives and agreements ratified by Spain [94]; the same criteria are expressed in the Law on Natural Heritage and Biodiversity [83].

\section{Results and Discussion}

3.1. At the European Level. Cypripedium calceolus L. and Spiranthes aestivalis (Poir.) Rich. are the two only orchid species included in the Habitats Directive whose distribution area includes Spain [77]. No orchid species whose distribution area includes Spain appear in the Berne Convention [78].

3.2. At the National Level. Although this report follows the nomenclature suggested by Flora iberica [76], which includes a total of 89 Iberian species belonging to 25 different genera, this study also adds four species of Canarian orchid flora not present in the Iberian orchid flora (adding the genus Habenaria, which is not present in the Iberian Peninsula): Habenaria tridactylites Lindl., Himantoglossum metlesicsianum (W. P. Teschner) P. Delforge, Orchis canariensis Lindl., and Serapias mascaensis H. \& G. Kretschner \& Kreutz. There are also three species not listed in Flora iberica as individual species, but as a synonym of species already described above. However, the three species were identified as individual species after the publication of the corresponding volume of Flora iberica in which the family Orchidaceae is described [76]. These three species are as follows:

(i) Dactylorhiza cantabrica H.A. Pedersen: this species was named as Dactylorhiza insularis Ó. Sánchez \& Herrero [76]; it was described as new species for Lugo in 2006 [118].

(ii) Orchis robusta (Steph.) Gölz \& H. R. Reinhard: this species was described as Orchis laxiflora subsp. robusta Lam. [52] or as Orchis palustris Jacq. var. robusta T. Steph. [76]. It is now considered endemic of La Albufera de Mallorca (Balearic Islands) as a separate species according to several authors. Bateman and collaborators, in their molecular studies, treated it as a species next to Orchis palustris Jacq., but independent of it; they even proposed a combination of O. robusta within Anacamptis robusta (T. Steph.) Bateman [49]. Authors such as Delforge also consider O. robusta a different species of all of them [44]. However, Tyteca and Klein combine O. robusta, A. robusta, and $O$. palustris in a different genus with the name Herorchis robusta (T. Stephenson) Tyteca \& Klein [60].

(iii) Serapias occidentalis C. Venhuis \& P. Venhuis: this species was included within Serapias vomeracea (Buró. Fil.) Briq. It has been proposed as a new species by hybridization of Serapias vomeracea subsp. vomeracea (Burm. fil.) Briq. $x$ Serapias cordigera L. at Badajoz (Extremadura) [119].

Therefore, this work considers a total of 96 species present in Spain belonging to the Orchidaceae family.
Once the National Catalogue of Threatened Species [79] was revised, no orchid species were found; subsequent additions and modifications included $H$. metlesicsianum in the Danger of Extinction category (included as B. metlesicsiana) [80] and subsequently C. calceolus in the same category [81].

In the recent update of the CNEA in 2011 [82], the two species listed first ( $H$. metlesicsianum and $C$. calceolus) have the same category of protection, and two more species are added in the List of Wild Species in Regime of Special Protection, Orchis provincialis Balb. and S. aestivalis.

O. provincialis presents a kind of Mediterranean distribution that restricts its presence mainly to the northern and western areas of the Iberian Peninsula. S. aestivalis is dispersed throughout almost all of the Iberian Peninsula, though more commonly found in the north and west and in specific habitats that are vulnerable to tampering, such as peat bogs, quagmires, reed beds, and wet heaths [76].

The Law of Natural Heritage and Biodiversity [83] implements the National Catalogue of Threatened Species [79], which includes two species of orchids, C. calceolus, within Appendix II (Animal and Plant Species of Community Interest Whose Conservation is Necessary to Designate Special Areas of Conservation), and S. aestivalis, within Appendix V (Animal and Plant Species of Community Interest Requiring a Strict Protection).

The categories of threat to species listed in Table 1 are those described by the International Union for the Conservation of Nature [120].

Threatened Species

$$
\begin{aligned}
& \text { CR: Critically Endangered } \\
& \text { EN: Endangered } \\
& \text { VU: Vulnerable }
\end{aligned}
$$

\section{Not Threatened Species}

\section{NT: Near Threatened \\ LC: Least Concerned \\ DD: Data Deficient}

Out of the 96 species of orchids present in the Iberian Peninsula, Balearic Islands, and Canary Islands, 16 species are included in the Red List of Spanish Vascular Flora (Table 1) [86], which were already included in the Red List of the Threatened Spanish Vascular Flora of 2008 [85]; five of these species are catalogued as not threatened species (i.e., NT, LC, or DD categories), which means that around $12-17 \%$ (depending on whether those five species are included) of the Spanish orchid flora are listed with some degree of threat nationwide, according to the 2010 Red List. Out of these 16 species, there are only two Canarian species- $H$. metlesicsianum and $O$. canariensis. So, if these two Canarian threatened species are omitted, there would be 14 species (or 9 species, if those five species mentioned above are not considered) with some degree of threat out of a total of 92 Iberian species (excluding the four species from the Canary Islands), that is, around $10-15 \%$ of the Iberian orchid flora. 
TABLE 1: The sixteen species included in 2010 Red List of Spanish Vascular Flora (RL) [86] following IUCN threat categories [120]. It is shown if they are included in any regional catalogue $(\mathrm{RC})$ and the threat category within them, as well as if they are included in any other catalogue of protected species.

\begin{tabular}{|c|c|c|c|}
\hline & Threat category in RL & $\begin{array}{l}\text { Regional catalogues (RC) } \\
\text { and threat category }\end{array}$ & Other catalogues \\
\hline Corallorhiza trifida Châtel. & $\mathrm{CR}(\mathrm{EN})^{*}$ & $\begin{array}{l}\text { RC of Aragón (Danger of } \\
\text { Extinction) } \\
\text { RC of Catalonia (Danger } \\
\text { of Extinction) }\end{array}$ & \\
\hline Cypripedium calceolus L. & $\mathrm{EN}$ & $\begin{array}{l}\mathrm{RC} \text { of Aragón (Danger of } \\
\text { Extinction) } \\
\mathrm{RC} \text { of Catalonia (Danger } \\
\text { of Extinction) }\end{array}$ & $\begin{array}{l}\text { CNEA (Danger of } \\
\text { Extinction) } \\
\text { Law Nat. Her. } \\
\text { Biodiv. (Danger } \\
\text { of Extinction) } \\
\text { Habitats Directive } \\
\text { Aragón } \\
\text { Recuperation } \\
\text { Plan }\end{array}$ \\
\hline $\begin{array}{l}\text { Dactylorhiza cantabrica } \mathrm{H} \text {. } \\
\text { A. Pedersen }\end{array}$ & VU & & \\
\hline $\begin{array}{l}\text { Dactylorhiza insularis } \\
\text { (Som.) O. Sánchez \& } \\
\text { Herrero }\end{array}$ & $\mathrm{LC}$ & $\begin{array}{l}\text { RC of Extremadura } \\
\text { (Special Interest) }\end{array}$ & \\
\hline $\begin{array}{l}\text { Dactylorhiza sulphurea } \\
\text { (Link) Franco }\end{array}$ & $\mathrm{LC}$ & $\begin{array}{l}\text { RC of Castilla y León } \\
\text { (Preferential Attention) }\end{array}$ & $\begin{array}{l}\text { RL Basque } \\
\text { Country (CR) } \\
\text { RL Andalusia } \\
\text { (DD) }\end{array}$ \\
\hline $\begin{array}{l}\text { Epipactis phyllanthes G. E. } \\
\text { Sm. }\end{array}$ & VU & & $\begin{array}{l}\text { RL Basque } \\
\text { Country (CR) }\end{array}$ \\
\hline Epipogium aphyllum Sw. & CR & $\begin{array}{l}\text { RC of Catalonia (Danger } \\
\text { of Extinction) }\end{array}$ & \\
\hline $\begin{array}{l}\text { Gymnadenia odoratissima } \\
\text { (L.) Rich }\end{array}$ & $\mathrm{DD}(\mathrm{VU})^{*}$ & $\begin{array}{c}\text { RC of Catalonia } \\
\text { (Vulnerable) } \\
\text { RC of Castilla y León } \\
\text { (Preferential Attention) }\end{array}$ & \\
\hline $\begin{array}{l}\text { Himantoglossum } \\
\text { metlesicsianum (W. P. } \\
\text { Teschner) P. Delforge }\end{array}$ & $\mathrm{EN}$ & $\begin{array}{l}\text { RC of Canary Islands } \\
\text { (Interest for Canarian } \\
\text { Ecosystems) }\end{array}$ & $\begin{array}{l}\text { CNEA (Danger of } \\
\text { Extinction) }\end{array}$ \\
\hline $\begin{array}{l}\text { Nigritella gabasiana } \\
\text { Teppner \& E. Klein }\end{array}$ & $\mathrm{LC}(\mathrm{VU})^{*}$ & $\begin{array}{c}\text { RC of Catalonia } \\
\text { (Vulnerable) } \\
\text { RC of Castilla y León } \\
\text { (Preferential Attention) }\end{array}$ & $\begin{array}{c}\text { RL Basque } \\
\text { Country (CR) }\end{array}$ \\
\hline Orchis canariensis Lindl. & VU & & \\
\hline $\begin{array}{l}\text { Orchis robusta (Steph.) } \\
\text { Gölz \& H. R. Reinhard }\end{array}$ & CR & & \\
\hline $\begin{array}{l}\text { Orchis spitzelii Saut.ex W. } \\
\text { D. J. Koch }\end{array}$ & $\mathrm{CR}$ & $\begin{array}{l}\text { RC of Catalonia (Danger } \\
\text { of Extinction) }\end{array}$ & \\
\hline Serapias nurrica Corrias & VU & $\begin{array}{c}\text { RC of Balearic Islands } \\
\text { (Vulnerable) }\end{array}$ & \\
\hline $\begin{array}{l}\text { Serapias occidentalis C. \& P. } \\
\text { Venhuis }\end{array}$ & VU & & \\
\hline $\begin{array}{l}\text { Serapias perez-chiscanoi } \\
\text { Acedo }\end{array}$ & $\mathrm{NT}(\mathrm{VU})^{*}$ & $\begin{array}{l}\text { RC of Extremadura } \\
\text { (Danger of Extinction) }\end{array}$ & \\
\hline
\end{tabular}

* Species included in 2000 Red List of Spanish Vascular Flora (VV.AA, 2000) with another threatened category. 
3.2.1. Threatened Species: Critically Endangered (CR). At the national level, there are four species listed as Critically Endangered (CR), according to the 2010 Red List of Spanish Vascular Flora: Corallorhiza trifida Châtel., Epipogium aphyllum Sw., O. robusta, and Orchis spitzelii Saut. ex. W. D. J. Koch (Table 1) [86].

C. trifida. In the 2000 Red List of Threatened Vascular Flora of Spain, this species was listed as Endangered (EN), having gone to be classified as Critically Endangered (CR) in the 2008 Red List of Threatened Vascular Flora of Spain [85]; it went from having five $10 \times 10 \mathrm{Km}$ UTM coordinates in 2000 to only one $10 \times 10 \mathrm{Km}$ UTM in 2008 . This species is still included in the 2010 Red List of Spanish Vascular Flora [86]. On the other hand, this species appears in the RC of Aragón (Danger of Extinction) (Table 1), where it currently holds the only recently confirmed population (Ordesa, Huesca, Aragón) [87] and in the RC of Catalonia (Danger of Extinction) (Table 1), where it is probably extinct, since the four populations that correspond to four $10 \times$ $10 \mathrm{Km}$ UTM coordinates have not been confirmed recently [87]. It should, therefore, be included in the CNEA and an urgent plan to recover such an endangered orchid should be developed.

E. aphyllum. This species is included in the 2010 Spanish Red List of Spanish Vascular Flora [86] and in the RC of Catalonia (Danger of Extinction) (Table 1), where its only population in the Pallars Sobirà of Lleida has not been confirmed recently; on the other hand, this species has two $10 \times 10 \mathrm{Km} \mathrm{UTM}$ more, one in Sierra Cebollera (La Rioja) and the other one between Huesca and Navarre, in the Valley of Linza (Huesca, Aragón) and the Belagua Valley (Navarre) [87]; therefore, it is suggested that this species should be included in the RC of Aragón, RC of Navarra, and RC of La Rioja, where it is currently not included, most likely because these catalogues are relatively old, dating back to 1995,1997 , and 1998, respectively. Of course, this species should be included in the CNEA as well.

O. robusta. Although its description dates from 1976 [121], this species has been recently discontinued as a subspecies [44, 49], meaning that it is included only in the 2008 and 2010 Red Lists of Spanish Vascular Flora $[85,86]$. It is endemic to the Balearic Islands and is found only in the Albufera of Mallorca (Balearic Islands). Therefore, O. robusta should be included in the CNEA as well as in the RC of Baleares.

O. spitzelli. Although this species is relatively widely distributed, with twenty-one $10 \times 10 \mathrm{Km}$ UTM coordinates, it currently only has a single $10 \times 10 \mathrm{Km}$ UTM recently confirmed in the Sierra del Cadí (Lleida, Catalonia). For this reason, this species is listed as Critically Endangered (CR) $[85,86]$ and it is only listed in the RC of Catalonia (Danger of Extinction) (Table 1), while it does not appear in the CNEA. Therefore, it is strongly suggested that this species be included in the CNEA.

These four species of orchids listed as Critically Endangered in Spain (CR) should have specific plans of recovery.
3.2.2. Threatened Species: Endangered (EN). There are two species classified as Endangered (EN) according to the 2010 Red List of Spanish Vascular Flora [86]: C. calceolus and $H$. metlesicsianum.

C. calceolus. This species is most likely, among all species of orchids included in the 2010 Red List of Spanish Vascular Flora, the species that is included in the most catalogues of protection, is the most studied, and has the most protection, since the threat to this species in the Iberian Peninsula was detected more than twenty years ago, being, along with $S$. aestivalis, the only two species protected in Spain that are included in the Habitats Directive [77]. In addition, $C$. calceolus and $H$. metlesicsianum are the only two species of Spanish orchids included in the CNEA in the category Danger of Extinction [82] and the only species, along with $S$. aestivalis, which are included in the Law of Natural Heritage and Biodiversity [83]. C. calceolus is also included in the RC of Aragón (Table 1) and the RC of Catalonia (Table 1) and has appeared in the Atlas and Red Book of the Threatened Vascular Flora of Spain since 2004 [87]. This is the only orchid that has a Plan of Recovery in Spain [90]. Since the distribution of C. calceolus in Spain is restricted to Aragón and Catalonia, it does not seem necessary to include this species in any other catalogue, neither regional nor national.

H. metlesicsianum. This is one of the two Canarian species-along with $O$. canariensis (VU)-which are included in the 2010 Red List of Spanish Vascular Flora (Table 1) [86]. H. metlesicsianum, whose distribution is restricted to Tenerife island (Canary Islands), has been included in the Atlas and Red Book of the Threatened Vascular Flora of Spain since 2004 [87] and it is included in the CNEA [80, 82] and the RC of the Canary Islands [104]; therefore, this species does not need to be included in any other protection catalogue.

3.2.3. Vulnerable Species (VU). The vulnerable orchid species include D. cantabrica, Epipactis phyllanthes G.E. Sm., O. canariensis, Serapias nurrica Corrias and S. occidentalis.

There are sixteen species included in the Red List of Spanish Vascular Flora (Table 1) [86], and four of them are not included in any other national or regional catalogue. Three of these species are the above-mentioned $D$. cantabrica, $O$. canariensis and S. occidentalis. The fourth one is O. robusta (CR), which was discussed above.

These three species-O. robusta, D. cantabrica, and $S$. occidentalis-most likely are in the Red List and no other catalogue because they have recently been described as separate species $[49,118,119]$; O. canariensis has not been described so recently but shows a relatively restricted distribution (Lanzarote and Fuerteventura; Canary Islands). Undoubtedly, the most troubling case is O. robusta, which is classified as Critically Endangered (CR); the other species, recent description or not, are not urgent in the short term, since they are classified as vulnerable (VU).

Nevertheless, and with the exception of S. nurrica and $E$. phyllanthes, none of the other three listed species as VU are found in any catalogue of protection; the recommendation 
would be to include those five species within the CNEA; in addition, D. cantabrica, which has been cited in O'Couto and Caurel (Lugo, Galicia), should be included in the RC of Galicia; E. phyllanthes, cited in Liencres (Santander, Cantabria) and Gorliz (Vizcaya, Basque Country), should be included in the RC of Cantabria and the RC of the Basque Country (although it is already included in the Red List of the Basque Country [93]); O. canariensis, endemic to the Canary Islands (Lanzarote and Fuerteventura) should be included in the $\mathrm{RC}$ of the Canary Islands; S. occidentalis, cited in Campo Lugar, Obanco, and Aljucén (Cáceres, Extremadura), should be included in the RC of Extremadura.

3.2.4. Other Categories, Not Threatened Species: Near Threatened (NT), Least Concern (LC), and Data Deficient (DD). As species catalogued as Near Threatened (NT), nationally, only Serapias perez-chiscanoi Acedo is included in the 2010 Red List of Spanish Vascular Flora [86] (Table 1); this species, in the 2000 Red List of Threatened Vascular Flora of Spain [84], had been classified as Vulnerable (VU), but the recent discovery of new populations of this species has led to its cataloguing as NT since 2008 [19, 85, 122]. This species is endemic to Portugal and Spain and more specifically to Extremadura (in Spain). This species is included in the RC of Extremadura as a species in Danger of Extinction [112]. Given that this regional catalogue is nine years older than the Spanish Red List, it explains that it seems not to be updated.

A second group of species under no threat at the national level but included in the 2010 Red List of Spanish Vascular Flora [86] are classified as Least Concerned (LC); in this group are D. insularis, Dactylorhiza sulphurea (Link) Franco, and Nigritella gabasiana Teppner \& E. Klein.

D. insularis. This species is also included in the RC of Extremadura [112] as a species of Special Concern, since, without being regulated in any of the categories of greatest threat (Endangered, Sensitive to Alteration of Their Habitat, Vulnerable), it is worthy of particular attention on the basis of its scientific, ecological, and cultural value or by its singularity [112].

D. sulphurea. This species is included in the RC of Castilla y León [109] as one of Preferential Attention, since, without meeting the conditions to be attached to any of the categories of greatest threat (Endangered, Vulnerable, Sensitive to Alteration of Their Habitat, and Of Special Attention), the species is scarce in Castilla y León, presenting threatened or reduced populations, which could be affected by different disturbances or that are linked to habitats in regression [109]. Additionally, the species is classified as Vulnerable in the RC of the Basque Country (included as Dactylorhiza markusii (Tineo) H. Baumann \& Künkele) [102]. It has also been recently included in the Red List of the Basque Country as Critically Endangered (CR) [93], which suggests that its status in the RC of the Basque Country as Vulnerable should be changed to Critically Endangered (CR). It was also included in the Red List of the Vascular Flora of Andalusia in the category of Data Deficient (DD) [92].
N. gabasiana. At the national level, this species was included as Vulnerable (VU) in the 2000 Red List of Threatened Vascular Flora of Spain [84], listed as Least Concern (LC) in the 2008 Red List of Threatened Vascular Flora of Spain [85], and remains so catalogued [86]. Additionally, it is classified as a Rare species in the RC of the Basque Country [102], and it is also included in the Red List of the Basque Country as Critically Endangered (CR) [93]; this fact does suggest that the status of this species in the RC of Basque Country as Rare should be changed to Critically Endangered (CR). It is also listed as Preferential Attention in the RC of Castilla y León, since, without meeting the conditions to be attached to any of the categories of greatest threat (Endangered, Vulnerable, Sensitive to Alteration of Their Habitat, and Of Special Attention), the species is scarce in Castilla y León, showing threatened or reduced populations and that they could be affected by different disturbances or are linked to habitats in regression [109].

Finally, Gymnadenia odoratissima (L.) Rich is classified at the national level as Data Deficient (DD) according to the 2010 Red List of Spanish Vascular Flora [86]. At the regional level, this species is listed as Preferential Attention in the $\mathrm{RC}$ of Castilla y León, since, without meeting the conditions to be attached to any of the categories of greatest threat (Endangered, Vulnerable, Sensitive to Alteration of Their Habitat, and Of Special Attention), it is scarce in Castilla y León, presenting threatened or reduced populations and that they could be affected by different disturbances or are linked to habitats in regression [109]. This species is catalogued as Vulnerable according to RC of Catalonia [110].

3.3. At the Regional Level. At the regional level, from the review of the corresponding seventeen regional catalogues of each autonomous Spanish community and the two existing regional red lists for Andalusia and the Basque Country $[92,93]$, the following results emerge.

Out of the 96 species of orchids existing in Spain, up to a total of 69 are included in any catalogue of regional protection or regional red list (including 12 of 16 protected species nationwide), that is, around $72 \%$. Only four out of the sixteen species included in the 2010 Red List of Spanish Vascular Flora are not included in any regional catalogue nor any regional red list (D. cantabrica, O. canariensis, O. robusta, and S. occidentalis) (Table 1) [86]. If both, the species included in the national and regional catalogues are considered, that is, also including these four species, and then 73 species are included in some catalogue of protection, which means that $76 \%$ of the Spanish orchid flora are listed with some figure of legal protection.

In Tables 2-20 are the species of orchids included in each of the regional catalogues and the cataloguing as protected species for each autonomous community, indicating the piece of legislation that regulates it. These tables are as follows.

Table 2 specifies the species included in the regional catalogue that lists endangered species of Andalusia [94, 95]; Table 3 specifies those species that are included in the Red List of the Vascular Flora of Andalusia [92]; Table 4 is for Aragón [96, 98]; Table 5 is for Asturias [99]; Table 6 is for the Balearic Islands [100]; Table 7 is for the Basque Country 
TABLE 2: Species included in the regional catalogue (RC) of Andalusia (DEC 23/2012).

\begin{tabular}{lc}
\hline \multicolumn{2}{c}{ RC of Andalusia (LAW 8/2003; DEC. 23/2012) } \\
\hline Neottia nidus-avis (L.) Rich & Vulnerable \\
Ophrys atlantica Munby & Vulnerable \\
Ophrys speculum Link subsp. lusitanica & Vulnerable (before as in \\
O. Danesch \& E. Danesch & Danger of Extinction) \\
Spiranthes spiralis (L.) Chevall. & Wild species in \\
\hline
\end{tabular}

TABLE 3: Species included in the Red List of the Vascular Flora of Andalusia [92].

\begin{tabular}{|c|c|}
\hline Red List of Andalusia & \\
\hline $\begin{array}{l}\text { Dactylorhiza markusii (Tineo) H. Baumann } \\
\text { \& Künkele = D. sulphurea (Link) Franco }\end{array}$ & $\mathrm{DD}$ \\
\hline Dactylorhiza sulphurea (Link) Franco ${ }^{*}$ & $\mathrm{DD}$ \\
\hline Epipactis lusitanica D. Tyteca & DD \\
\hline Epipactis microphylla (Ehrh.) Sw. & DD \\
\hline Gennaria diphylla (Link) Parl. & $\mathrm{VU}$ \\
\hline $\begin{array}{l}\text { Gymnadenia conopsea (L.) R. Br. in W.T. } \\
\text { Aiton }\end{array}$ & $\mathrm{VU}$ \\
\hline Listera ovata (L.) R. Br. in W.T. Aiton & DD \\
\hline Neottia nidus-avis (L.) Rich ${ }^{* *}$ & $\mathrm{EN}$ \\
\hline Ophrys atlantica Munby ${ }^{* *}$ & $\mathrm{DD}$ \\
\hline $\begin{array}{l}\text { Ophrys speculum Link subsp. lusitanica O. } \\
\text { Danesch \& E. Danesch** }\end{array}$ & $\mathrm{DD}$ \\
\hline Orchis palustris Jacq. & $\mathrm{DD}$ \\
\hline Platanthera algeriensis Batt. \& Trab. & $\mathrm{DD}$ \\
\hline Spiranthes spiralis (L.) Chevall.** & $\mathrm{DD}$ \\
\hline
\end{tabular}

TABLE 4: Species included in the regional catalogue (R.C.) of Aragón (DEC. 49/1995; ORD. 2004/03/04).

\begin{tabular}{ll}
\hline RC of Aragón (DEC. 49/1995; ORD. 4/03/2004; DEC. 181/2005) \\
\hline Corallorhiza trifida Châtel. & In Danger of Extinction \\
Cypripedium calceolus L. &
\end{tabular}

Ophrys riojana C. E. Hermos. $=O$. Sensitive to Habitat Alteration sphegodes Mill.

Orchis simia Lam.

Vulnerable

${ }^{*}$ Species included in the 2010 Red List of Spanish Vascular Flora (Table 1) [86].

TABLE 5: Species included in the regional catalogue (RC) of Asturias (DEC. 65/1995).

\begin{tabular}{l} 
RC of Asturias (DEC. 65/1995) \\
\hline None \\
\hline
\end{tabular}

[101-103]; Table 8 specifies those species that are included in the Red List of the Vascular Flora of the Basque Country [93]; Table 9 is for Canary Islands [104, 105]; Table 10 is for Cantabria [106]; Table 11 is for Castilla-La Mancha [107, 108]; Table 12 is for Castilla y León [109]; Table 13 is for Catalonia
TABLE 6: Species included in the regional catalogue (RC) of Balearic Islands (DEC. 65/1995).

\begin{tabular}{lc}
\hline \multicolumn{2}{c}{ RC of Balearic Islands (DEC. 75/2005) } \\
\hline Cephalanthera rubra (L.) Rich. & Vulnerable \\
Gymnadenia conopsea (L.) R. Br. in W.T. Aiton & Vulnerable \\
Neottia nidus-avis (L.) Rich. & Vulnerable \\
Orchis cazorlensis Lacaita & Vulnerable \\
Orchis palustris Jacq. & Vulnerable \\
Serapias nurrica Corrias* & Vulnerable \\
\hline${ }^{*}$ Species included in the 2010 Red List of Spanish Vascular Flora (Table1) [86].
\end{tabular}

TABLE 7: Species included in the regional catalogue (RC) of Basque Country (ORD. 3471/1998).

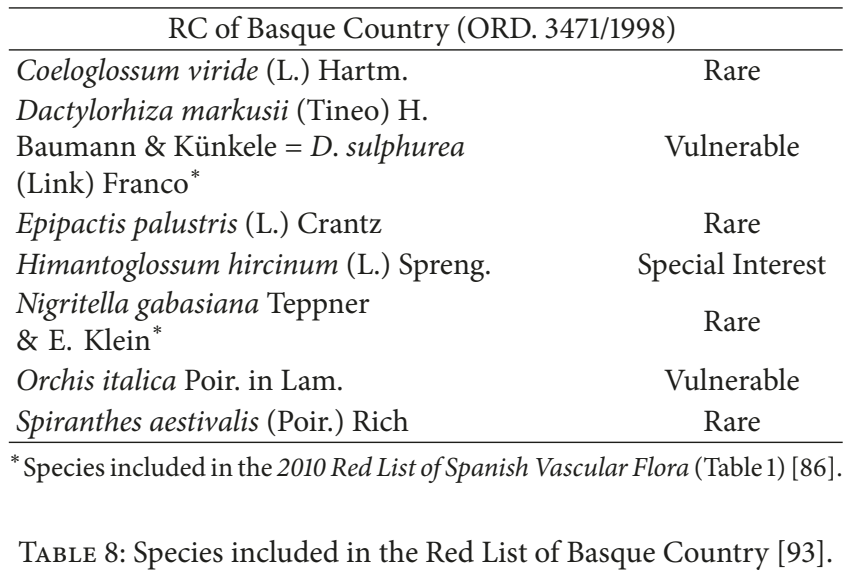

\begin{tabular}{|c|c|}
\hline \multicolumn{2}{|c|}{ Red List of Basque Country } \\
\hline Barlia robertiana (R. J. Loisel) Greuter** & CR \\
\hline Coeloglossum viride (L.) Hartm. & VU \\
\hline Dactylorhiza sulphurea (Link) Franco* & CR \\
\hline Epipactis palustris (L.) Crantz & VU \\
\hline Epipactis phyllanthes G. E. Sm.*** & $\mathrm{CR}$ \\
\hline Himantoglossum hircinum (L.) Spreng & NT \\
\hline Nigritella gabasiana Teppner \& E. Klein* & CR \\
\hline Ophrys aveyronensis (J. J. Wood) P. & \\
\hline Delforge in P. Delforge \& D. Tyteca** & $\nabla U$ \\
\hline Orchis cazorlensis Lacaita** & $\mathrm{CR}$ \\
\hline Orchis italica Poir. in Lam. & $\mathrm{VU}$ \\
\hline Orchis papilionacea L.** & $\mathrm{DD}$ \\
\hline Spiranthes aestivalis (Poir.) Rich & VU \\
\hline
\end{tabular}

${ }^{*}$ Species included in the 2010 Red List of Spanish Vascular Flora (Table 1) [86]. ${ }^{* *}$ Species not included in the RC of Basque Country.

TABLE 9: Species included in the regional catalogue (RC) of Canary Islands (DEC. 151/2001; LAW 4/2010).

RC of Canary Islands (DEC. 151/2001; LAW 4/2010)

Himantoglossum metlesicsianum Interest for Canary Ecosystems (W. P. Tesch.) P. Delforge ${ }^{*} \quad$ (before as in Danger of Extinction)

${ }^{*}$ Species included in the 2010 Red List of Spanish Vascular Flora (Table 1) [86].

TABLE 10: Species included in the regional catalogue (RC) of Cantabria (DEC. 120/2008).

RC of Cantabria (DEC. 120/2008)

Epipactis palustris (L.) Krantz In Danger of Extinction


TABLE 11: Species included in the regional catalogue (R.C.) of Castilla-La Mancha (DEC. 33/1998; DEC. 200/2001).

\begin{tabular}{lr}
\hline & \multicolumn{2}{c}{ R.C of Castilla-La Mancha (DEC. 33/1998; DEC. 200/2001) } \\
\hline Aceras anthropophorum (L.) W. T. Aiton & Special Interest \\
Coeloglossum viride (L.) Hartm. & Special Interest \\
Dactylorhiza incarnata (L.) Soó & Vulnerable \\
Dactylorhiza sambucina (L.) Soó & Vulnerable \\
Dactylorhiza spp. & Special Interest \\
Epipactis distans Arv.-Touv. & Special Interest \\
Epipactis palustris (L.) Crantz & Special Interest \\
Gymnadenia conopsea (L.) R. Br. in W. T. Aiton & Special Interest \\
Himantoglossum hircinum (L.) Spreng. & Special Interest \\
Listera ovata (L.) R. Br. in W. T. Aiton & Special Interest \\
Neottia nidus-avis (L.) Rich & Special Interest \\
Ophrys insectifera L. & Vulnerable \\
Platanthera spp. & Special Interest \\
Serapias cordigera L. & Special Interest \\
\hline
\end{tabular}

TABLE 12: Species included in the regional catalogue (RC) of Castilla y León (DEC. 63/2007).

\begin{tabular}{lr}
\hline & RC of Castilla y León (DEC. 63/2007) \\
\hline Barlia robertiana (R.J.Loisel) Greuter & Preferential Attention \\
Dactylorhiza sulphurea (Link) Franco ${ }^{*}$ & Preferential Attention \\
Epipactis fageticola (C.E. Hermos.) Devillers-Tersch. \& Devillers & Preferential Attention \\
Epipactis microphylla (Ehrh..) Sw. & Preferential Attention \\
Epipactis palustris (L.) Crantz & Preferential Attention \\
Epipactis tremolsii Pau & Preferential Attention \\
Gymnadenia odoratissima (L.) Rich ${ }^{*}$ & Preferential Attention \\
Nigritella gabasiana Teppner \& E. Klein ${ }^{*}$ & Preferential Attention \\
Ophrys insectifera L. & Preferential Attention \\
Orchis cazorlensis Lacaita & Preferential Attention \\
Orchis conica Willd. & Preferential Attention \\
Orchis pallens L. & Preferential Attention \\
Orchis papilionacea L. & Preferential Attention \\
Orchis provincialis Balb. ex. Lam. \& D.C & Preferential Attention \\
Platanthera algeriensis Batt. \& Trab. & Vulnerable \\
Platanthera chlorantha (Custer) Rchb. in Mössler & Preferential Attention \\
Pseudorchis albida (L.) Á. Löve \& D. Löve & Preferential Attention \\
Spiranthes aestivalis (Poir.) Rich & Preferential Attention \\
\hline
\end{tabular}

${ }^{*}$ Species included in the 2010 Red List of Spanish Vascular Flora (Table 1) [86].

[110]; Table 14 is for Comunidad Valenciana [111]; Table 15 is for Extremadura [112]; Table 16 is for Galicia [113]; Table 17 is for La Rioja [114]; Table 18 is for Madrid [115]; Table 19 is for Murcia [116]; Table 20 is for Navarre [117].

The Red List of Andalusia (Table 3; $[94,95]$ ) is not an official list with legislation but should serve as a basis for whether to include certain species in the RC of Andalusia (Table 2). Andalusia's RC has one notable absence, D. sulphurea. In addition, Gennaria diphylla (Link) Parl. and Gymnadenia conopsea (L.) R. Br. in W. T. Aiton, both listed as VU in the Red List of Andalusia, should be included as well in the RC of Andalusia [92].

The RC of Aragón [96], its update being relatively recent [97, 98] (Table 4), seems to collect the most endangered species in this region, some of them clearly nationally threatened, such as C. trifida and C. calceolus (Table 1) [86]; however, it would be convenient to include E. aphyllum, a species included in the 2010 Red List of Spanish Vascular Flora as a Critically Endangered species (CR) (Table 1) [86].

In the case of Asturias [99] (Table 5), despite its great biodiversity of flora, including orchids, the RC of Asturias does not include any species of the Orchidaceae family.

In the RC of the Balearic Islands [100] (Table 6), the presence of $S$. nurrica is notable, as it is also included in the 2010 Red List of Spanish Vascular Flora (VU) (Table 1) [86]. The inclusion of $O$. robusta in the regional catalogue should be pressing, as it is already included in the $2010 \mathrm{Red}$ List of Spanish Vascular Flora as Critically Endangered (CR) (Table 1) [86].

The Red List of the Basque Country [93] (Table 8) includes the seven species of the RC of the Basque Country, generally with degrees of threat greater than those designated 
TABLE 13: Species included in the regional catalogue (RC) of Catalonia (DEC. 172/2008).

\begin{tabular}{|c|c|}
\hline \multicolumn{2}{|c|}{ RC of Catalonia (DEC. 172/2008) } \\
\hline Coeloglossum viride (L.) Hartm. & Strictly Protected \\
\hline Corallorhiza trifida Châtel. ${ }^{*}$ & In Danger of Extinction \\
\hline Cypripedium calceolus L.* & In Danger of Extinction \\
\hline Epipogium aphyllum Sw. ${ }^{*}$ & In Danger of Extinction \\
\hline Gymnadenia odoratissima (L.) Rich ${ }^{*}$ & Vulnerable \\
\hline $\begin{array}{l}\text { Ophrys catalaunica (O. Danesch \& E. } \\
\text { Danesch.) Soca = O.bertolonii } \\
\text { Moretti subsp. catalaunica (O. } \\
\text { Danesch \& E. Danesch.) Soca }\end{array}$ & Strictly Protected \\
\hline Orchis palustris Jacq. & Vulnerable \\
\hline Orchis spitzelii Saut. ex W. D. J. Koch* & In Danger of Extinction \\
\hline Spiranthes aestivalis (Poir.) Rich & Vulnerable \\
\hline
\end{tabular}

* Species included in the 2010 Red List of Spanish Vascular Flora (Table 1) [86].

in the RC of the Basque Country: both D. sulphurea and N. gabasiana are listed as $\mathrm{CR}$, and the other species listed as Rare in the RC of the Basque Country (C. viride, E. palustris, and S. spiralis) are catalogued in the Red List of the Basque Country as VU, as well as Orchis italic Por in Lam., which is still listed as VU. The seventh species, Himantoglossum hircinum (L.) Spreng., is catalogued as Special Interest in the RC of the Basque Country whereas in the Red List of the Basque Country it is catalogued as Near Threatened. The Red List of the Basque Country adds to these seven species five more: $E$. phyllanthes, which is listed as CR in the Basque Country and as VU at the national level according to the 2010 Red List of Spanish Vascular Flora (Table 1) [86]; Barlia robertiana (R. J. Loisel) Greuter and Orchis cazorlensis Lacaita, both listed as CR; Ophrys aveyronensis (J. J. Wood) P. Delforge in P. Delforge \& D. Tyteca as VU; and Orchis papilionacea L., which is classified as DD [93]. It would be advisable, therefore, to include at least $E$. phyllanthes within the RC of the Basque Country, a species cited in this community only at Gorliz (Bilbao). It would also be advisable to include the other four species, especially the two species listed as CR (B. robertiana and $O$. cazorlensis) and to a lesser extent $O$. aveyronensis (VU) and O. papilionacea (DD).

The RC of the Canary Islands $[104,105]$ (Table 9), which includes $H$. metlesicsianum (included as B. metlesicsiana. in the category Extinction Danger) [104], should be expanded with O. canariensis, included in the 2010 Red List of Spanish Vascular Flora as Vulnerable (VU) (Table 1) [86].

The RC of Cantabria [106] (Table 10) includes only one species, Epipactis palustris (L.) Crantz; however, it seems clear that $E$. phyllanthes should be included as well, as it is included in the 2010 Red List of Spanish Vascular Flora as a vulnerable species (VU) (Table 1) [86], cited only at Liencres (Santander, Cantabria).

Table 11 shows the species included in the regional catalogue of endangered species of Castilla-La Mancha [107, 108].

Table 12 shows the species included in the regional catalogue of endangered species in Castilla y León [109]. It is an extensive list, with eighteen species, three of which are included in the 2010 Red List of Spanish Vascular Flora: G. odoratissima (DD), D. sulphurea (LC), and N. gabasiana (LC) (Table 1) [86]; however, O. spitzelii is not included and perhaps it should be due to the few populations of this species in this region [22]; this species is included in the $2010 \mathrm{Red}$ List of Spanish Vascular Flora as Critically Endangered (CR) (Table 1) [86].

Table 13 specifies those species included in the regional catalogue of endangered species in Catalonia [110]. Although it is not a very extensive listing, as it includes only a total of nine species, it is the regional catalogue that includes a greater number of species that are included in the 2010 Red List of Spanish Vascular Flora (Table 1) [86], with five species, most of them as Critically Endangered (CR: C. trifida, E. aphyllum, and O. spitzelii) or Endangered (EN: C. calceolus) at the national level, all of them catalogued as in Danger of Extinction according to the RC of Catalonia; only G. odoratissima (DD) is not threatened according to the Spanish Red List, classified as Vulnerable according to the RC of Catalonia. Therefore, and considering that it is one of the most recent catalogues, the regional catalogue of Catalonia seems to be very up to date. It should be noted that it is the only regional catalogue to include O. spitzelii, an endangered species according to the 2010 Red List of Spanish Vascular Flora (Table 1) [86], which is also exceptionally present in other autonomous communities such as Castilla y León or Aragón (not confirmed in Aragón).

Table 14 specifies the species included in the regional catalogue of endangered species of Comunidad Valenciana [111]. This is one of the most recent regional catalogues of endangered species of Spain; evidence of this recentness is its thoroughness, with a total of 41 species included (39 if synonyms are taken into account), although only $D$. insularis is included nationally in the 2010 Red List of Spanish Vascular Flora (LC) (Table 1) [86]. This catalogue appears to be updated as it is one of the most recent regional catalogues, and it lists a large number of species.

The Regional Catalogue of Extremadura [112] (Table 15) contains two of the species included in the 2010 Red List of Spanish Vascular Flora (Table 1) [86]-D. insularis and S. perez-chiscanoi; in the case of the latter, catalogued for Extremadura as Endangered and however listed nationally as Near Threatened (NT) according to the 2010 Red List of Spanish Vascular Flora (Table 1) [86], it seems clear that its status should change regionally to a degree of minor threat. It would be useful to include in this catalogue S. occidentalis, a species highly located in Extremadura, specifically at Campo Lugar, Obanco, and Aljucén (Cáceres). It should be listed as VU according to the 2010 Red List of Spanish Vascular Flora (Table 1) [86].

In the case of the Regional Catalogue of Galicia [113] (Table 16), with only one species, $S$. aestivalis $(\mathrm{Vu})$, it should at least include $D$. cantabrica, catalogued nationally as VU according to the 2010 Red List of Spanish Vascular Flora (Table 1) [86] and cited only at O'Couto (Caurel, Lugo).

The Regional Catalogue of La Rioja [113] (Table 17) does not collect any species of the Orchidaceae family; it is recommended to include, at least, E. aphyllum, with 
TABLE 14: Species included in the regional catalogue (RC) of Comunidad Valenciana (DEC. 70/2009).

\begin{tabular}{|c|c|}
\hline \multicolumn{2}{|c|}{ RC of Comunidad Valenciana (DEC. 70/2009) } \\
\hline Aceras anthropophorum (L.) W. T. Aiton & Watched species \\
\hline Barlia robertiana (R. J. Loisel) Greuter & Protected species not catalogued \\
\hline Cephalanthera damasonium (Mill.) Druce & Watched species \\
\hline Coeloglossum viride (L.) Hartm. & Vulnerable \\
\hline Dactylorhiza fuchsii (Druce) Soó & Watched species \\
\hline Dactylorhiza incarnata (L.) Soó & Vulnerable \\
\hline Dactylorhiza insularis (Som.) O. Sánchez \& Herrero* & Vulnerable \\
\hline Dactylorhiza maculata (L.) Soó & Protected species not catalogued \\
\hline Dactylorhiza sambucina (L.) Soó & Watched species \\
\hline Epipactis atrorubens Hoffm. ex Besser & Watched species \\
\hline Epipactis distans & Watched species \\
\hline Epipactis fageticola & Vulnerable \\
\hline Epipactis palustris (L.) Crantz & Protected species not catalogued \\
\hline Epipactis rhodanensis Gévaudar \& Robatsch & Watched species \\
\hline Epipactis tremolsii Pau & Watched species \\
\hline Goodyera repens (L.) R. Br. in W. T. Aiton & Watched species \\
\hline Gymnadenia conopsea (L.) R. Br. in W. T. Aiton & Watched species \\
\hline Limodorum trabutianum Batt. & Watched species \\
\hline Listera ovata (L.) R. Br. in W. T. Aiton & Protected species not catalogued \\
\hline Neottia nidus-avis (L.) Rich & Protected species not catalogued \\
\hline Ophrys castellana Devillers-Tesch. \& Devillers = O. sphegodes Mill. & Protected species not catalogued \\
\hline Ophrys incubacea Bianca = O. sphegodes Mill. & Protected species not catalogued \\
\hline Ophrys sphegodes Mill. & Watched species \\
\hline Orchis cazorlensis Lacaita & Protected species not catalogued \\
\hline Orchis collina Banks \& Sol. ex. Russell & Vulnerable \\
\hline Orchis conica Willd. & Vulnerable \\
\hline Orchis coriophora L. subsp. martrinii (Timb.-Lagr.) Nyman & Watched species \\
\hline Orchis fragrans (Pollini) K. Richt. = O. coriophora L. subsp. fragrans (Pollini) K. Richt. & Protected species not catalogued \\
\hline Orchis italica Poir. in Lam. & Watched species \\
\hline Orchis langei K. Richt. & Watched species \\
\hline Orchis papilionacea L. & In Danger of Extinction \\
\hline Orchis picta (Loisl.) K. Richt. = O. morio L. subsp. picta (Loisl.) K. Richt. & Watched species \\
\hline Orchis purpurea Huds. & Vulnerable \\
\hline Orchis ustulata L. & Protected species not catalogued \\
\hline Platanthera bifolia (L.) Rich & Protected species not catalogued \\
\hline Platanthera chlorantha (Custer) Rchb. in Mössler & Protected species not catalogued \\
\hline Serapias lingua L. & Vulnerable \\
\hline Serapias parviflora Parl. & Protected species not catalogued \\
\hline Serapias strictiflora Welw. ex Veiga & Vulnerable \\
\hline Spiranthes aestivalis (Poir.) Rich & In Danger of Extinction \\
\hline Spiranthes spiralis (L.) Chevall. & Watched species \\
\hline
\end{tabular}

${ }^{*}$ Species included in the 2010 Red List of Spanish Vascular Flora (Table 1) [86].

one population in Sierra Cebollera and listed nationally as Critically Endangered (CR) according to the 2010 Red List of Spanish Vascular Flora (Table 1) [86].

The Regional catalogue of the Comunidad de Madrid is the most ancient of the many catalogues in Spain [115] (Table 18), including only two species-Platanthera bifolia (L.) Rich and Neottia nidus-avis (L.) Rich. The list of possible species to be included is long, with very specific or apparently extinct species in this autonomous community, as evidenced by recent studies [38]. These species include Aceras anthropophorum (L.) W. T. Aiton, Anacamptis pyramidalis (L.) Rich, Barlia robertiana (R. J. Loisel) Greuter, Cephalanthera rubra (L.) Rich, D. insularis, Dactylorhiza sambucina (L.) Soó, G. conopsea, H. hircinum, Limodorum trabutianum Batt., Listera 
TABLE 15: Species included in the regional catalogue (RC) of Extremadura (DEC. 37/2001).

\begin{tabular}{|c|c|}
\hline \multicolumn{2}{|l|}{ RC of Extremadura (DEC. 37/2001) } \\
\hline Cephalanthera rubra (L.) Rich & Special Interest \\
\hline Dactylorhiza insularis (Som.) O. Sánchez \& Herrero* & Special Interest \\
\hline Limodorum trabutianum Batt. & Vulnerable \\
\hline Neottia nidus-avis (L.) Rich & Vulnerable \\
\hline $\begin{array}{l}\text { Ophrys dyris (Maire) Soó in G. Keller Schltr. \& Soó = O. fusca Linksubsp. dyris (Maire) Soó in G. Keller Schltr. } \\
\text { \& Soó }\end{array}$ & Special Interest \\
\hline Orchis italica Poir. in Lam. & Special Interest \\
\hline Orchis langei K. Richt. & Special Interest \\
\hline Orchis papilionácea L. & Special Interest \\
\hline Serapias perez-chiscanoi Acedo* & In Danger of Extinction \\
\hline Spiranthes aestivalis (Poir.) Rich & Special Interest \\
\hline
\end{tabular}

${ }^{*}$ Species included in the 2010 Red List of Spanish Vascular Flora (Table 1) [86].

TABLE 16: Species included in the regional catalogue (RC) of Galicia (DEC. 88/2007).

\begin{tabular}{ll}
\hline \multicolumn{2}{c}{ RC of Galicia (DEC. 88/2007) } \\
\hline Spiranthes aestivalis (Poir.) Rich & Vulnerable \\
\hline
\end{tabular}

TABLE 17: Species included in the regional catalogue (R.C.) of La Rioja (DEC. 59/1998).

\begin{tabular}{l}
\hline R.C. of La Rioja (DEC. 59/1998) \\
\hline None
\end{tabular}

TABLE 18: Species included in the regional catalogue (RC) of Madrid (DEC. 18/1992).

\begin{tabular}{ll}
\hline \multicolumn{2}{c}{ RC of Madrid (DEC. 18/1992) } \\
\hline Platanthera bifolia (L.) Rich & Vulnerable \\
Neottia nidus-avis (L.) Rich & Vulnerable \\
\hline
\end{tabular}

ovata (L.) R. Br. in W.T. Aiton, Neotinea maculata (Desf.) Stearn., Ophrys fusca Link, Orchis papilionacea L., Serapias cordigera L. and Spiranthjes spiralis (L.) Chevall.

Murcia's RC [116] (Table 19) seems to be up to date, since it is quite recent, dating from the year 2003, and it includes twelve species.

Opposite to Murcia's RC in terms of timeliness is that of Navarre's RC [117] (Table 20), which includes only one species, Orchis papilionacea. This catalogue should be reviewed, and it should include at least E. aphyllum, with one population at the Belagua Valley and that appears in the 2010 Red List of Spanish Vascular Flora as a species in critical Danger of Extinction (CR) (Table 1) [86].

3.4. Statistical Analysis. After conducting a joint analysis of the different regional catalogues, the following observations can be made.

Table 21 refers to the main genera that have been included in regional catalogues of protected species the most, indicating the number of times that each genus has been included in a regional catalogue and the number of species of this genus that have been included in a regional catalogue. The table also
TABLE 19: Species included in the regional catalogue (RC) of Murcia (DEC. 50/2003).

\begin{tabular}{lc}
\hline \multicolumn{2}{c}{ RC of Murcia (DEC. 50/2003) } \\
\hline Aceras anthropophorum (L.) W.T. Aiton & Vulnerable \\
Barlia robertiana (R.J.Loisel) Greuter & Vulnerable \\
Cephalanthera rubra (L.) Rich & Vulnerable \\
Dactylorhiza elata (Poir.) Soó & Vulnerable \\
Epipactis cardina Benito \& C.E. & Special \\
Hermos. & Interest \\
Himantoglossum hircinum (L.) Spreng. & Vulnerable \\
Listera ovata (L.) R. Br. in W.T. Aiton & Vulnerable \\
Ophrys incubacea Bianca = O. & Special \\
sphegodes Mill. & Interest \\
Orchis cazorlensis Lacaita & Vulnerable \\
Orchis purpurea Huds. & Vulnerable \\
Serapias lingua L. & Vulnerable \\
Serapias parviflora Parl. & Vulnerable \\
\hline
\end{tabular}

TABLE 20: Species included in the regional catalogue (RC) of Navarre (DEC. 94 /1997).

\begin{tabular}{lr}
\hline \multicolumn{2}{c}{ RC of Navarre (DEC. Foral 94/1997) } \\
\hline Orchis papilionacea L.
\end{tabular}

specifies the number of species for each genus at the national level following Flora iberica [76].

Figure 1 represents the genera whose species mostly have been included in the set of 17 regional catalogues. The genera that include large numbers of species and are therefore most likely to be present in many autonomous communities are also those that are included in a larger number of regional catalogues, stressing above all the genus Orchis, with 28 inclusions of different species in the regional catalogues, which precisely shows the greater number of species at the national level (21 species) (Table 21; Figure 1) [76]. In fact, if a correlation is made between the number of species that those genera have at the national level and the number of times that those genera have been included in any regional catalogue 
TABLE 21: Number of species by genus in Spain [76], number of times that they are included in regional catalogues (RC) by genus, and number of species included in regional catalogues (RC) by genus.

\begin{tabular}{lccc}
\hline & Number of spp./genus & Number of times in RC/genus & Number of spp. included in RC/genus \\
\hline Orchis & 21 & 28 & 16 \\
Epipactis & 14 & 15 & 8 \\
Ophrys & 12 & 11 & 9 \\
Dactylorhiza & 9 & 10 & 8 \\
Serapias & 8 & 8 & 6 \\
Spiranthes & 2 & 9 & 2 \\
Neottia & 1 & 6 & 1 \\
\hline
\end{tabular}

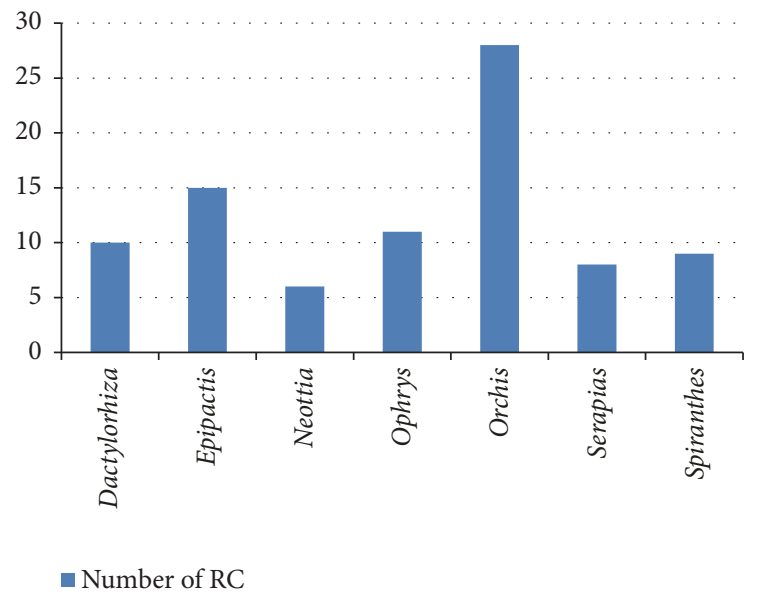

FIGURE 1: Genera mostly represented in regional catalogues (RC).

(represented by any kind of species that belong to that genus), the correlation is quite high $\left(R^{2}=0.79\right)$ (Figure 2).

At the opposite end, there are the genera Neottia, single grazing (Neottia nidus-avis (L.) Rich), and Spiranthes, with two species (S. aestivalis and S. spiralis), which are included in six and nine regional catalogues, respectively.

In a complementary manner, in Figure 3 there are the genera with a larger number of species included in the regional catalogues, showing similar results to those in Figure 1 but excluding Neottia and Spiranthes, as they are only represented by one and two species, respectively.

For Figure 3, the results are more homogenous, and, except for Orchis, which remains standing with 16 species included in various regional catalogues, the other genera are represented through six to nine species in the different regional catalogues. This drop in the number of species is because several species are repeated in several catalogues, but there are really not so many different species, especially in the case of Orchis and Epipactis, featuring 28 and 15 appointments in different regional catalogues (Figure 1) corresponding to 16 and 8 species, respectively (Figure 3, Table 21). The correlation between the number of species per genus and the number of species that are included in regional catalogue per genus continues to present a high determination coefficient $\left(R^{2}=\right.$ 0.88 ; figure not shown). Likewise, if the number of times that a genus is included in any regional catalogue is correlated with the number of species of that genus included in regional

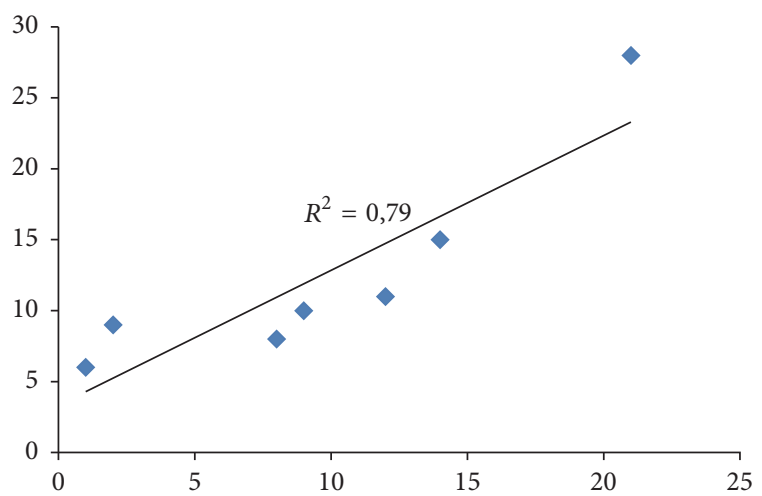

FIGURE 2: Relationship of regression between the number of species per genus and the number of regional catalogues (RC) in which each genus is included.

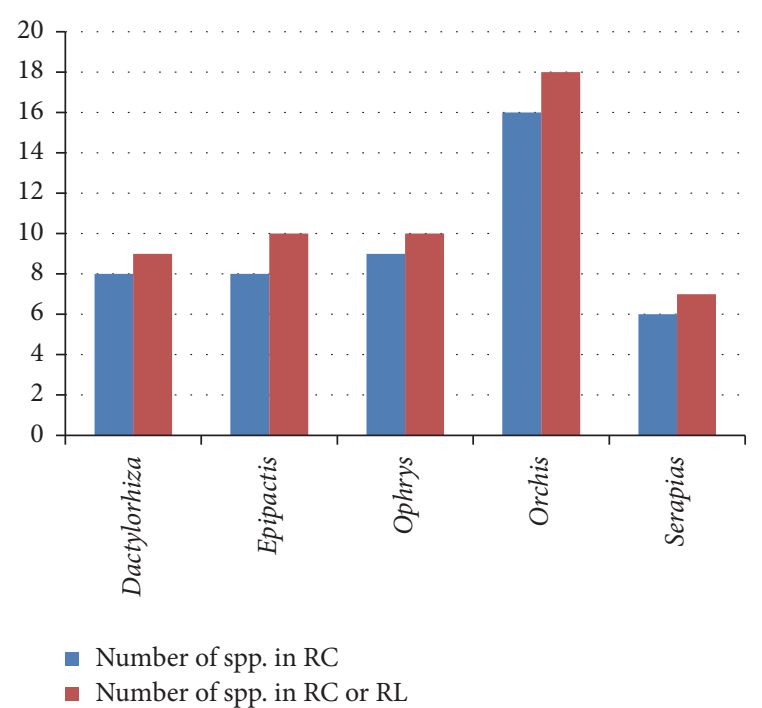

FIGURE 3: Genera with the highest number of species included in the regional catalogues. At the same time, the numbers of species included in regional catalogues and regional red lists are included.

catalogues, the correlation is quite high $\left(R^{2}=0.92\right.$; figure not shown), as expected.

Similarly, Figure 4 represents the species that are included in the greatest number of regional catalogues, highlighting $S$. aestivalis and N. nidus-avis, found in seven and six regional 
TABLE 22: Number of species included in each regional catalogue, indicating in each case the most recent legislation that regulates it, as well as the need of an urgent modification, the minimum species to include in it, and their figure of protection-if it exists-according to the 2010 Red List of Spanish Vascular Flora [86] (Table 1).

\begin{tabular}{|c|c|c|c|}
\hline $\begin{array}{l}\text { Regional } \\
\text { catalogue }\end{array}$ & $\begin{array}{l}\text { Number } \\
\text { of spp. }\end{array}$ & $\begin{array}{l}\text { Needs } \\
\text { modification? }\end{array}$ & Species to include \\
\hline $\begin{array}{l}\text { Andalusia } \\
\text { (DEC. } 23 / 2012)\end{array}$ & 4 & YES & $\begin{array}{c}\text { Dactylorhiza sulphurea (Link) Franco (LC) } \\
\text { Gennaria diphylla (Link) Parl. } \\
\text { Gymnadenia conopsea (L.) R. Br. in W.T. } \\
\text { Aiton }\end{array}$ \\
\hline $\begin{array}{l}\text { Aragón (DEC. } \\
185 / 2005)\end{array}$ & 4 & YES & Epipogium aphyllum Sw. (CR) \\
\hline $\begin{array}{l}\text { Asturias (DEC. } \\
65 / 1995)\end{array}$ & 0 & YES & Undetermined \\
\hline $\begin{array}{l}\text { Balearic Islands } \\
\text { (DEC. 75/2005) }\end{array}$ & 6 & YES & $\begin{array}{c}\text { Orchis robusta (Steph.) Gölz \& H.R. } \\
\text { Reinhard (CR) }\end{array}$ \\
\hline $\begin{array}{l}\text { Basque Country } \\
\text { (ORD. } \\
\text { 3471/1998; ORD. } \\
\text { 3901/2003) }\end{array}$ & 7 & YES & $\begin{array}{l}\text { Barlia robertiana (Lois.) Greuter (CR) } \\
\text { Epipactis phyllanthes G.E. Sm. (VU) } \\
\text { Orchis cazorlensis Lacaita } \\
\text { Orchis papilionacea L. } \\
\text { Ophrys aveyronensis (J.J. Wood) P. Delforge } \\
\text { in P. Delforge \& D. Tyteca }\end{array}$ \\
\hline $\begin{array}{l}\text { Canary Islands } \\
\text { (LEY 4/2010) }\end{array}$ & 1 & YES & Orchis canariensis (VU) \\
\hline $\begin{array}{l}\text { Cantabria } \\
\text { (DEC. 120/2008) }\end{array}$ & 1 & YES & Epipactis phyllanthes G.E. Sm. (VU) \\
\hline $\begin{array}{l}\text { Castilla-La } \\
\text { Mancha }\end{array}$ & & NO & - \\
\hline \multicolumn{4}{|l|}{$\begin{array}{l}\text { (DEC. 33/1998; } \\
\text { DEC. 200/2001) }\end{array}$} \\
\hline $\begin{array}{l}\text { Castilla y León } \\
\text { (DEC. 63/2007) }\end{array}$ & 18 & YES & Orchis spitzelii Saut ex.W.D.J.Koch (CR) \\
\hline $\begin{array}{l}\text { Catalonia } \\
\text { (DEC. } 172 / 2008)\end{array}$ & 9 & NO & - \\
\hline $\begin{array}{l}\text { Com. } \\
\text { Valenciana } \\
\text { (DEC. 70/2009) }\end{array}$ & 41 & NO & 皮 \\
\hline $\begin{array}{l}\text { Extremadura } \\
\text { (DEC. } 37 / 2001)\end{array}$ & 10 & YES & $\begin{array}{l}\text { Serapias occidentalis C. \& P. Venhuis (VU) } \\
\quad \text { Serapias perez-chiscanoi Acedo (NT) }\end{array}$ \\
\hline $\begin{array}{l}\text { Galicia (DEC. } \\
88 / 2007)\end{array}$ & 1 & YES & Dactylorhiza cantabrica H.A.Peders. (VU) \\
\hline $\begin{array}{l}\text { La Rioja (DEC. } \\
59 / 1998)\end{array}$ & 0 & YES & Epipogium aphyllum Sw. (CR) \\
\hline $\begin{array}{l}\text { Madrid (DEC. } \\
\text { 18/1992) }\end{array}$ & 2 & YES & Undetermined \\
\hline $\begin{array}{l}\text { Murcia (DEC. } \\
50 / 2003)\end{array}$ & 12 & NO & - \\
\hline $\begin{array}{l}\text { Navarre (DEC. } \\
\text { F. 94/1997) }\end{array}$ & 1 & YES & Epipogium aphyllum Sw. (CR) \\
\hline
\end{tabular}

catalogues, respectively. None of the six most cited species in regional catalogues (four to seven cites) are included in the 2010 Red List of Spanish Vascular Flora [86], which is indicative of their wide national distribution, although in certain autonomous communities they are scarce; however, $S$. aestivalis is included in the CNEA [82].

Table 22 constitutes a compendium of the results after analysing the global set of 17 regional catalogues. The table indicates, for each one of these regions, the law by which its regional catalogue was created or its most recent modification (and therefore the year), the number of listed species, and if, based on the results mentioned above, an urgent modification is considered; it also includes the species most urgent to include in each catalogue and its conservation status if it exists, according to the Red List of Spanish Vascular Flora [86] (Table 1). 


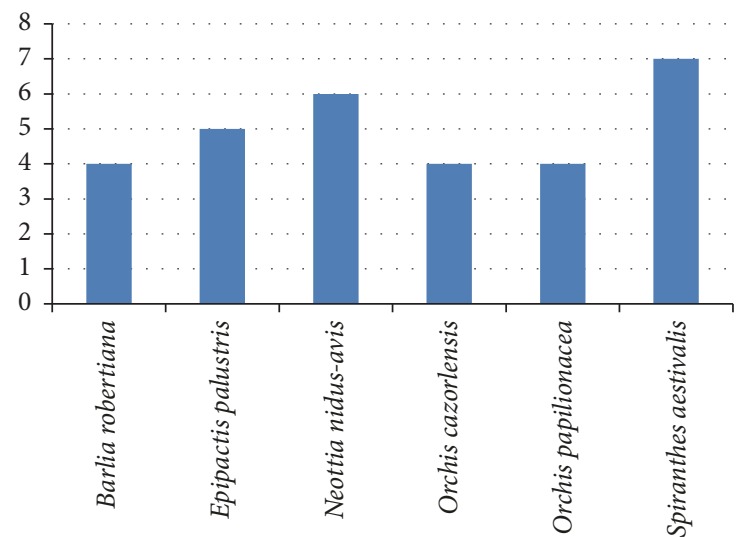

- Number of times in RC

FIGURE 4: Species mostly included in regional catalogues (RC).

As evident in Table 22, there is no clear relationship between how recent each regional catalogue is and the number of protected species included in it $\left(R^{2}=0.1\right.$; figure not shown); nevertheless, it is quite obvious for some regional catalogues that seem obsolete, as in the cases of Madrid [115], Asturias [99], Navarre [117], La Rioja [114], and Basque Country [103], with antiquities from 11 to 21 years, with no update since then. These regional catalogues clearly require updating, and they must include some species to protect, as in the case of E. aphyllum in Aragón, La Rioja, and Navarre, or multiple species that appear necessary to include in the catalogue of Madrid according to De la Torre \& Gamarra [38], which in fact is the oldest regional catalogue of Spain; however, there are also quite recent catalogues that need to be updated in a broad way, such as the cases of Andalusia [94], the Canary Islands [105], Cantabria [106], and Galicia [113].

However, if the correlation is made between the antiquity of the catalogue and the number of species suggested to include, in this case, an acceptable correlation is obtained $\left(R^{2}=0.38\right.$; figure not shown), amounting to $R^{2}=0.57$ if the curious case of Andalusia mentioned above is not taken into account (figure not shown). Although this regional catalogue dates from 2012, it is suggested to include at least four more species based on the Red List of the Vascular Flora of Andalusia [92]. For this regression, ten species are taken as the number of species to be included in the regional catalogue of Madrid, according to De la Torre and Gamarra [38]; in the case of Asturias, considering that the region has a more recent catalogue, six species have been taken as the number of species to be included in that regional catalogue. These results indicate that there is a direct correlation between the antiquity of the regional catalogue and the number of species to be included.

A fact that must be considered when making such correlations is that not all the Spanish regions have the same floristic richness and that, logically, those regions with more variable and more sensitive habitats tend to house vulnerable species and will be more likely to protect a greater number of species. Such is the case of the regions hosting the country's major mountain ranges, such as regions of Northern Spain and Cantabrian and Pyrenean (Galicia, Asturias, Cantabria, Basque Country, Navarre, and Catalonia) and the mountainous regions of the Centre-North (Castilla y León, Madrid) or South (Andalusia), where on average there are more than 16 genera of orchids, as opposed to other regions with a low diversity of orchids (Murcia, Aragón) [123].

\section{Conclusions}

There are no orchid species whose distribution area includes Spain that are included in the Berne Convention [78], and there are only two species included in the Habitats Directive [77]: C. calceolus, which is the species that is best protected at a legal level, and S. aestivalis.

Out of the 96 species of the Spanish orchid flora considered in this review, up to 73 species are included in any catalogue of protection; 16 are in the 2010 Red List of Spanish Vascular Flora (five of them not endangered) [86], and 69 are included in any catalogue of regional protection or regional red list (including 12 of the 16 species included in the aforementioned red list); that is, around $76 \%$ of the Spanish orchid flora are listed with any figure of protection or included in any red list, either nationally (about 12-17\%) or regionally (72\%). Only four out of the sixteen species included in the 2010 Red List of Spanish Vascular Flora are not included in any regional catalogue although they should be (Table 1, [86]).

The National Catalogue of Threatened Species (CNEA) lists a total of four species: $H$. metlesicsianum (Endangered) [80, 82], C. calceolus (Endangered) [81, 82], and O. provincialis and $S$. aestivalis (both as Wild Species in Regime of Special Protection) [82]. It is suggested that, in successive revisions of the CNEA, the other 14 species included in the 2010 Red List of Spanish Vascular Flora should be included-except for $C$. calceolus (EN) and H. metlesicsianum (EN), which are already included [86] (Table 1). Moreover, it is strongly suggested to include those species listed as Critically Endangered (CR) and Vulnerable (VU) and to a lesser extent the other species listed as Near Threatened (NT) and as Least Concern (LC) and those listed as Data Deficient (DD). In addition, the elaboration of specific plans of recovery for those species listed as Critically Endangered (CR) is suggested.

The genera mostly included in regional catalogues and which have a greater number of species in regional catalogues are precisely those genera that have a higher number of species at the national level: Orchis, Epipactis, Ophrys, Dactylorhiza, and Serapias; moreover, Spiranthes and Neottia, despite being bispecific and single grazing, respectively, are within the genera most included in regional catalogues. These latter two genera represent the two species most often included in regional catalogues: S. aestivalis and N. nidusavis, which appear in seven and six regional catalogues, respectively.

Only three out of the seventeen regional catalogues of endangered species do not seem to need an immediate update: the RC of Catalonia [110], the RC of Comunidad Valenciana [111], and the RC of Murcia [116]. 
It is remarkable that the $\mathrm{RC}$ of Catalonia [110] is the one that lists the most species that are included in the Red List of Spanish Vascular Flora [86], a total of five species: C. trifida (CR), E. aphyllum (CR), O. spitzelii (CR), C. calceolus (EN), and G. odoratissima (DD).

The other fourteen regional catalogues would need to be modified to a greater or lesser extent, highlighting the RC of Madrid [115], which is the oldest of them all and probably the most obsolete; it is believed that at least ten species would need to be included [38]. The RC of Asturias is also quite old [99] and does not feature any orchid species. The regional catalogues of Andalusia [94] and the Basque Country [102], mainly thanks to the red lists of these two autonomous communities [92, 93], need to be incorporate at least four and five additional species, respectively (Table 22).

Several regional catalogues should also be highlighted for their remarkable absences: The RC of Aragón [98] should be modified to include E. aphyllum (CR) and perhaps O. spitzelii (CR) (its presence not confirmed); the RC of the Balearic Islands [100] should be modified to include O. robusta (CR), a species endemic to this autonomous community; the RC of the Canary Islands [105] should include O. canariensis (VU), a species endemic to this autonomous community; the RC of Extremadura [112] should include S. occidentalis (VU), which is endemic to Extremadura; the RC of Galicia [113] should include $D$. cantabrica, endemic to this autonomous community.

The main species that are listed in the 2010 Red List of Spanish Vascular Flora [86] and that would need to be included in several regional catalogues are the following:

Orchis spitzelli (CR): this species should be included in the regional catalogue of Castilla y León.

Epipogium aphyllum (CR): this species should be incorporated into three regional catalogues: Aragón, La Rioja, and Navarre.

Epipactis phyllanthes (VU): this species should be included in two regional catalogues: Cantabria and Basque Country.

\section{Additional Points}

The findings of this work summarize the legislative knowledge about orchid conservation at several levels for Spain and should be a helpful guideline for environmental policies about orchid's conservation in Spain, at least at the regional and national level. These results will be presented to the Spanish Society for Biological Conservation of Plants (SEBiCoP).

\section{Conflicts of Interest}

The author declares that there are no conflicts of interest regarding the publication of this paper.

\section{References}

[1] V. Cutanda, "Flora compendiada de Madri," in D Y Su Provincia, p. 759, Ed. Carlos Bailly-Bailiére, Madrid, Spain, 1861.
[2] M. Willkomm, Prodromus Florae Hispanicae 1, Stuttgart, Germany, 1861.

[3] J. D’Ascenção Guimarães, "Orchideographia portugueza," Boletin Sociedad Broteroana, vol. 5, pp. 17-84, 1887.

[4] S. Rivas Goday, Revisión de las orquídeas de España, Universidad Complutense de Madrid, Spain, 1930.

[5] A. Ceballos, "Las orquídeas españolas," Bol. Estac. Centr. Escol, vol. 2, no. 3, pp. 29-39, 1973.

[6] J. Molero Mesa, F. A. Pérez Raya, and J. M. Martínez Parras, Martínez Parras JM. 1981. Relación de las Orchidaceae de la provincia de Granada, vol. 37, Anales del Jardin Botánico de Madrid, 2nd edition, 1981.

[7] F. Pérez Raya and J. Molero Mesa, Orquídeas silvestres de la provincia de Granada, Universidad de Granada, 1990.

[8] M. Van der Sluys and J. González Atarbe, Orquídeas de Navarra, Diputación Foral de Navarra. Instituto Príncipe de Viana, 1982.

[9] D. Tyteca, “The orchid flora of Portugal," Journal Europäischer Orchideen, vol. 29, no. 2, pp. 185-581, 1997.

[10] D. Tyteca and B. Tyteca, "Orchidées du Portugal - 11. Esquisse systématique, chorologique et cartographique," in Naturalistes Belges, vol. 67, pp. 163-192, 5-6 edition, 1986.

[11] D. Rivera Núñez and G. López Vélez, Orquídeas de la provincia de Albacete, Instituto de Estudios Albacetenses, Serie I. Ensayos Históricos y Científicos 31. Excma. Diputación de Albacete, Albacete, Spain, 1987.

[12] M. Becerra Parra and E. Robles Domínguez, Guia De Campo De Las Orquídeas Silvestres De Andalucía, Ed. La Serranía, Ronda, Málaga, Spain, 2009.

[13] H. Hertel, "Beiträge zur Verbreitung der Orchideen in Andalusien," Ber. Arbeitskr. Heimische Orchid, vol. 6, no. 1, pp. 106-111, 1989.

[14] G. Alomar, Petita guia de les orquídies de les Balears, Conselleria d'Agricultura i Pesca Govern Balear, Palma, Mallorca, Spain, 1994.

[15] K. Kreutz, "Beitrag zur Erforschung und Kenntnis einiger Orchideenkarten der Balearen," Insel Mallorca. Ber. Arbeitskr. Heimische Orchid, vol. 6, no. 1, pp. 115-128, 1989.

[16] P. Delforge, "Les orchidées de la Serranía de Cuenca (NouvelleCastille, Espagne). Observations et esquisse d'une cartographie," NaturalistesBelges, vol. 70, no. 3, pp. 99-128, 1989.

[17] E. Soto and A. Coronado, "Guía de las orquídeas de la provincia de Cuenca," in Diputación provincial de Cuenca, Diputación provincial de Cuenca, 2004.

[18] J. L. Pérez Chiscano, J. R. G. Llano, and F. Durán Oliva, "Orquídeas de extremadura," Fondo Natural, S. L, 1991.

[19] F. M. Vázquez Pardo, "Revisión de la familia Orchidaceae en Extremadura (España)," in Folia Botanica Extremadurensis, vol. 3, pp. 5-362, 2009.

[20] P. Bouillie, J. Bonilla, and C. F. López, "Orquídeas de la provincia de Jaén," Blancoana, vol. 9, pp. 102-111, 1992.

[21] P. Delforge, "Contribution à la connaissance des orchidées de la province de Burgos (Vieille Castille, Espagne)," Naturalistes Belges, vol. 76, no. 8, pp. 232-276, 1995.

[22] P. Galán Cela, "Datos previos para un catálogo de las orquídeas burgalesas," Anales del Jardin Botánico de Madrid, vol. 43, no. 1, pp. 65-82, 1986.

[23] L. Marín Padellano and P. G. Cela, Catálogo de las orquídeas silvestres de la provincia de Burgos, Catálogo de las orquídeas silvestres de la provincia de Burgos, Madrid, Spain, 1994. 
[24] O. Bolòs de and J. Vigó, Flora dels Països Catalans, IV Monocotiledònies, Editorial Barcino, Barcelona, Spain, 6th edition, 2001.

[25] J. Nuet, Atlesdorquidies de Catalunya, Publicacions de l'Abadía de Montserrat, 2011.

[26] H. Sanz Gonel and J. Nuet Badia, Guia de camp de les orquídies de Catalunya, Ed. Montblanc-Martín, 1995.

[27] M. R. Lowe, "Les Orchidées de la province d'Alicante," Naturalistes Belges, vol. 76, no. 8, pp. 78-83, 1995.

[28] J. Piera Olives, M. B. Crespo Villalba, and M. R. Lowe, Las orquídeas de la provincia de Alicante, Ed. Instituto Juan Gilbert, Alicante, Spain, 2003.

[29] M. R. Lowe, "The orchids of the province of Málaga, Spain," Journal Europäischer Orchideen, vol. 30, no. 3, pp. 501-570, 1998.

[30] A. Pallarés, Orquídeas de Almería, Almería, Spain, 1999.

[31] C. Cortizo and E. Sahuquillo, "La familia Orchidaceae en Galicia (N.O. Península Ibérica)," Nova Acta Cientifica Compostelana (Bioloxia), vol. 9, pp. 125-158, 1999.

[32] T. E. Díaz González and J. A. Fernández Prieto, Paisaje vegetal del noroeste ibérico. El litoral y orquídeas silvestres del territorio, Ediciones Trea, Gijón, Spain.

[33] J. Benito Ayuso, J. A. Alejandre, and J. A. Arizaleta, "Aproximación al catálogo de las orquídeas de la Rioja (España)," Estudios del Museo de Ciencias Naturales de Álava, vol. 14, pp. 19-64, 1999.

[34] X. Lizaur, "Orquídeas de Euskal Herría," Servicio Central de Publicaciones del Gobierno Vasco, Vitoria, 2001.

[35] J. A. López Espinosa and P. Sánchez Gómez, Orquídeas silvestres de la Región de Murcia, DM Librero Editor, Murcia, Spain, 2007.

[36] C. Muñoz Ortega, Orquídeas de Aragón, Ed. Jolube, 2014.

[37] C. Cebolla and M. A. Rivas Ponce, "Atlas florae matritensis," Fontqueria, vol. 41, 1, p. 203, 1994.

[38] D. De la Torre and R. Gamarra, “Aportación al conocimiento corológico y estado de conservación de la familia Orchidaceae en la Comunidad de Madrid," Biojournal, pp. 2-12, 2005.

[39] H. Baumann, R. Lorenz, and S. Künkele, Guía de Orquídeas de Europa, Groenlandia, Azores, Norte de África y Oriente Medio, Ed. Omega, Barcelona, Spain, 2007.

[40] K. P. Buttler, Field Guide to Orchids of Britain And Europe, The Crowood Press, Wiltshire, England, 1991.

[41] P. Delforge, Guide des Orchidées d'Europe, d'Afrique du Nord et du Proche-Orient, Delachaux et Niestlé, Lausanne, Paris, 1994.

[42] P. Delforge, Guide des orchid'ees d'Europe, dÁfrique du Nord et $d u$ Proche-Orient, Delachaux et Niestlé S. A., Lausanne, Paris, 2001.

[43] P. Delforge, Guía de las orquídeas de España y Europa, Norte de África y Próximo Oriente, Lynx Edicions, Barcelona, Paris, 2002.

[44] P. Delforge, Orchids of Europe, North Africa and the Middle East, Ed. Timber pr, 2006.

[45] A. Harrap and S. Harrap, Orchids of Britain and Ireland: A Field and Site Guide, A \& C Black, Londonm England, 2005.

[46] H. Sundermann, Europaïsche und mediterrane Orchideen, Hildesheim, 3rdedition, 1980.

[47] R. M. Bateman, "Evolution and classification of European orchids: insights from molecular and morphological characters," Journal Europäischer Orchideen, vol. 33, no. 1, pp. 33-119, 2001.

[48] R. M. Bateman, A. M. Pridgeon, and M. W. Chase, "Phylogenetics of subtribe Orchidinae (Orchidoideae, Orchidaceae) based on nuclear ITS sequences. 2. Infrageneric relationships and reclassification to achieve monophyly of Orchis sensu stricto," Lindleyana, vol. 12, no. 3, pp. 113-141, 1997.

[49] R. M. Bateman, P. M. Hollingsworth, J. Preston, L. Yi-Bo, A. M. Pridgeon, and M. W. Chase, "Molecular phylogenetics and evolution of Orchidinae and selected Habenariinae (Orchidaceae)," Botanical Journal of the Linnean Society, vol. 142, no. 1, pp. 1-40, 2003.

[50] R. L. Dressler, Phylogeny and Classification of the Orchid Family, Cambridge University Press, 1993.

[51] P. Galán Cela and R. Gamarra, "Check list of the iberian and balearic orchids. 1. Aceras R. Br. - Nigritella Rich," Anales del Jardin Botánico de Madrid, vol. 59, no. 2, pp. 187-208, 2002.

[52] P. Galán Cela and R. Gamarra, "Check list of the Iberian and Balearic Orchids 2. Ophrys L. - Spiranthes Rich," Anales del Jardin Botánico de Madrid, vol. 60, no. 2, pp. 309-329, 2003.

[53] R. Gamarra, E. Ortúñez, E. Sanz, I. Esparza, and P. Galán, “Seeds in subtribe Orchidinae (Orchidaceae): the best morphological tool to support molecular analyses," in Tools for Identifying Biodiversity: Progress and Problems, P. L. Nimis and R. Vignes Lebbe, Eds., Edizioni Università di Trieste, Trieste, Italy, 2010.

[54] E. Ortúñez, E. Dorda, P. Galán Cela, and R. Gamarra, Seed micromorphology in the Iberian Orchidaceae. I. Subfamily Cypripedioideae. Bocconea19, Seed micromorphology in the Iberian Orchidaceae. I. Subfamily Cypripedioideae. Bocconea19, 271274, 2006.

[55] A. M. Pridgeon, R. M. Bateman, A. V. Cox, J. R. Hapeman, and M. W. Chase, "Phylogenetics of subtribe Orchidinae (Orchidoideae, Orchidaceae) based on nuclear ITS sequences. 1. Intergeneric relationships and polyphyly of Orchis sensu lato," Lindleyana, vol. 12, no. 2, pp. 89-109, 1997.

[56] A. M. Pridgeon, P. J. Cribb, M. W. Chase, and F. N. Rasmussen, Eds., Genera Orchidacearum, vol. 1, Oxford University Press, 1, 1999.

[57] A. M. Pridgeon, P. J. Cribb, M. W. Chase, and F. N. Rasmussen, Eds., Genera Orchidacearum, vol. 2, Oxford University Press, 2001.

[58] A. M. Pridgeon, P. J. Cribb, M. W. Chase, and F. N. Rasmussen, Eds., Genera Orchidacearum. Orchidoideae (part two).Vanilloideae, vol. 3, Oxford University Press, 2003.

[59] A. M. Pridgeon, P. J. Cribb, M. W. Chase, and F. N. Rasmussen, Eds., Genera Orchidacearum, vol. 4. Epidendroideae (part one), vol. 4, Oxford University Press, Oxford, England, 2005.

[60] D. Tyteca and E. Klein, "Genes, morphology and biology The systematics of Orchidinae revisited," Journal Europäischer Orchideen, vol. 40, no. 3, pp. 501-544, 2008.

[61] H. Baumann and S. Künkele, "Die Gattung Serapias L. Eine taxonomische Übersicht," Bl. Arbeitskr Heim. Orch. BadenWürtt, vol. 21, no. 3, pp. 701-946, 1989.

[62] L. V. Averyanov, "A review of the genus Dactylorhiza," in Orchid Biology. Reviews and Perspectives, J. Arditti, Ed., pp. 159-206, Timber Press, Portland, ORE, USA, 1990.

[63] D. Tyteca, "Systematics and biostatistics of Dactylorhiza in western Europe: some recent contributions," Journal Europäischer Orchideen, vol. 33, no. 1, pp. 179-199, 2001.

[64] L. 1. Sáez, "The genus Nigritella (Orchidaceae) in the Iberian Peninsula," Anales del Jardin Botánico de Madrid, vol. 61, no. 1, pp. 81-90, 2004.

[65] H. Teppner and E. Klein, "Nigritella gabasiana spec. nova, N. nigra subsp. Iberica subsp. nova (Orchidaceae-Orchideae) und deren Embryologie," Phyton (Horn), vol. 33, no. 2, pp. 179-209, 1994. 
[66] H. Teppner and E. Klein, "Etiam atque etiam - Nigritella versus Gymnadenia: Neukombinationen und Gymnadenia dolomitensis spec. nova (Orchidaceae-Orchideae)," Phyton (Horn), vol. 38, no. 1, pp. 220-225, 1998.

[67] R. Gamarra, E. Dorda, A. Scrugli, P. Galán, and E. Ortúñez, "Seed micromorphology in the genus Neotinea Rchb.f. (Orchidaceae, Orchidinae)," Botanical Journal of the Linnean Society, vol. 153, no. 2, pp. 133-140, 2007.

[68] R. Gamarra, E. Ortúñez, P. G. Cela, and V. Guadaño, "Anacamptis versus Orchis (Orchidaceae): seed micromorphology and its taxonomic significance," Plant Systematics and Evolution, vol. 298, no. 3, pp. 597-607, 2012.

[69] H. Kretzschmar, W. Eccarius, and H. Dietrich, The Orchid Genera Anacamptis, Orchis, Neotinea, Echino Media Verlag, Bargel, 2007.

[70] R. Gamarra, P. Galán, I. Herrera, and E. Ortúnez, "Seed micromorphology supports the splitting of Limnorchis from Platanthera (Orchidaceae)," Nordic Journal of Botany, vol. 26, no. 1-2, pp. 61-65, 2008.

[71] R. Gamarra, E. Sanz, and I. Esparza, "Seed micromorphology in the genera Chamorchis and Traunsteinera (Orchidinae, Orchidaceae)," Journal Europäischer Orchideen, vol. 43, no. 1, pp. 119-130, 2011.

[72] S. Bernardos, A. Crespí, F. Del Rey, and F. Amich, "The section Pseudophrys (Ophrys, Orchidaceae) in the Iberian Peninsula: a morphometric and molecular analysis," Botanical Journal of the Linnean Society, vol. 148, no. 3, pp. 359-375, 2005.

[73] H. A. Pedersen and N. Faurholdt, Ophrys. The bee Orchids of Europe, Royal Botanic Garden, Kew, UK, 2007.

[74] F. M. Vázquez, S. Aguilar, D. García et al., "Biodiversidad vegetal en los espacios adehesados: monocotiledóneas bulbosas," in Gestión ambiental y económica del ecosistema dehesa en la Península Ibérica, M. Espejo, M. Martín, and F. J. Mesías, Eds., pp. 105-114, 2006.

[75] F. Pulido, R. Sanz, D. Abel et al., "Los bosques de Extremadura. Evolución, ecología y conservación," in Consejería de Industria, Energía y Medio Ambiente. Junta de Extremadura, p. 343, Badajoz, Spain, 2007.

[76] "Orchidaceae in: S. castroviejo (coord.) Flora iberica XXI. smilacaceae-orchidaceae," in Consejo Superior de Investigaciones Científicas, pp. 15-197, Madrid, Spain, 2005.

[77] DIRECTIVE 92/43/CEE, del Consejo de 21 de mayo de 1992, relativa a la conservación de los hábitats naturales y de la fauna y la flora silvestres.

[78] DECISSION 82/72/CEE del Consejo, de 3 de diciembre de 1981, referente a la celebración del Convenio relativo a la conservación de la vida silvestre y del medio natural de Europa.

[79] "ROYAL DECREE 439/1990, de 30 de Marzo, por el que se regula el Catálogo Nacional de Especies Amenazadas," B.O.E $\mathrm{n}^{\circ} 82$, de 5 de Abril.

[80] "ORDER de 9 de Julio de 1998, por la que se incluyen determinadas especies en el Catálogo Nacional de Especies Amenazadas y cambian de categoría otras especies que ya están incluidas en el mismo," B.O.E n¹72, de 20 de Julio.

[81] "ORDER MAM/2734/2002, de 21 de octubre, por la que se incluyen determinadas especies, subespecies y poblaciones en el Catálogo Nacional de Especies Amenazadas y cambian de categoría y se excluyen otras incluidas en el mismo," B.O.E $\mathrm{n}^{\circ} 265$, de 5 de Noviembre.

[82] "ROYAL DECREE 139/2011, de 4 de febrero, para el desarrollo del Listado de Especies Silvestres en Régimen de Protección
Especial y del Catálogo Español de Especies Amenazadas," B.O.E ${ }^{\circ} 46$, de 23 de Febrero.

[83] "LAW 42/2007, de 13 de diciembre, del Patrimonio Natural y de la Biodiversidad," B.O.E n²99, de 14 de Diciembre.

[84] F. Domínguez-Lozano, Ed., Lista Roja de la Flora Vascular Española (valoración según categorías IUCN), vol. 6, Conservación Vegetal, 2000.

[85] J. C. Moreno, "Lista Roja 2008 de la Flora Vascular Española," in Dirección General del Medio Natural y Política Forestal (Ministerio de Medio Ambiente y Medio Rural y Marino, y Sociedad Española de Biología de la Conservación de Plantas), p. 86, 2008 de la Flora Vascular Española. Dirección General del Medio Natural y Política Forestal (Ministerio de Medio Ambiente y Medio Rural y Marino, Madrid, Spain, 2008.

[86] Á. Bañares, G. Blanca, J. Güemes, J. C. Moreno, and S. Ortiz, "Atlas y Libro Rojo de la Flora Vascular Amenazada de España. Adenda 2010," in Dirección General de Medio Natural y Política Forestal (Ministerio de Medio Ambiente, y Medio Rural y Marino)-Sociedad Española de Biología de la Conservación de Plantas, p. 170, Madrid, Spain, 2010.

[87] “Atlas y Libro Rojo de la Flora Vascular Amenazada de España," in Dirección General de Conservación de la Naturaleza, p. 1069, 2004.

[88] Á. Bañares, G. Blanca, J. Güemes, J. C. Moreno, and S. Ortiz, Eds., Atlas y Libro Rojo de la Flora Vascular Amenazada de España. Adenda 2006, Dirección General para la Biodiversidad y Sociedad Española de Biología de la Conservación de Plantas, Madrid, Spain, 2007, pp. 92.

[89] Á. Bañares, G. Blanca, and J. Güemes, "Atlas y Libro Rojo de la Flora Vascular Amenazada de España. Adenda 2008Conservación de Plantas," in Dirección General de Medio Natural y Política Forestal y Sociedad Española de Biología de la Conservación de Plantas, JC. Moreno and S. Ortiz, Eds., p. 155, Madrid, Spain, 2009.

[90] "DECREE 234/2004, de 16 de Noviembre, del Gobierno de Aragón, por el que se establece un régimen de protección para el Zapatito de dama, Cypripedium calceolus L, y se aprueba su Plan de Recuperación,” B.O.A n¹41 de 1 de Diciembre.

[91] "AGREEMENT de 13 de marzo de 2012, del Consejo de Gobierno, por el que se aprueban los planes de recuperación y conservación de determinadas especies silvestres y hábitats protegidos de Andalucía," B.O.J.A nº60, de 27 de Marzo i.

[92] B. Cabezudo, S. Talavera, G. Blanca et al., Lista Roja de la Flora Vascular de Andalucía, Consejería de medio Ambiente. Junta de Andalucía, Sevilla, Spain, 2005.

[93] "Lista Roja de la Flora Vascular de la," in Departamento de Medio Ambiente, Planificación territorial, Agricultura y Pesca. Gobierno Vasco, p. 348, Madrid, Spain, 2010.

[94] "DECREE 23/2012, de 14 de febrero, por el que se regula la conservación y el uso sostenible de la flora y la fauna silvestres y sus hábitats en Andalucía," B.O.J.A n ${ }^{\circ} 60$, de 27 de Marzo.

[95] "LAW 8/2003, de 28 de Octubre, de la Flora y la Fauna Silvestres de Andalucía," B.O.J.A n²18, de 12 de Noviembre.

[96] “DECREE 49/1995, de 28 de Marzo, de la Diputación General de Aragón, por el que se regula el Catálogo de Especies Amenazadas de Aragón," B.O.A nº 42 , de 7 de Abril.

[97] "DECREE 181/2005, de 6 de septiembre, del Gobierno de Aragón, por el que se modifica parcialmente el Decreto 49/1995, de 28 de marzo, de la Diputación General de Aragón, por el que se regula el Catálogo de Especies Amenazadas de Aragón,” B.O.A. no 114 , de 23 de septiembre. 
[98] “ORDER de 4 de marzo de 2004, del Departamento de Medio Ambiente, por la que se incluyen en el Catálogo de Especies Amenazadas de Aragón determinadas especies, subespecies y poblaciones de flora y fauna y cambian de categoría y se excluyen otras especies ya incluidas en el mismo," B.O.A n³4, de 22 de Marzo.

[99] "DECREE 65/1995, de 27 de Abril, por el que se crea el Catálogo Regional de Especies Amenazadas de la Flora del Principado de Asturias y se dictan normas para su protección," B.O.P.A nº128, de 5 de Junio.

[100] "DECREE 75/2005, de 8 de Julio, por el cual se crea el Catálogo Balear de Especies amenazadas y de Especial Protección, las Áreas Biológicas Críticas y el Consejo Asesor de Fauna y Flora de les Illes Balears," B.O.I.B nº106, de 16 de Julio.

[101] "LAW 16/1994, de 30 de Junio, de conservación de la naturaleza del País vasco," B.O.P.V no 142, de 27 de Julio.

[102] "ORDER 3471 de 10 de Junio de 1998, del Consejero de Industria, Agricultura y Pesca por la que se incluyen en el Catálogo Vasco de Especies Amenazadas de la Fauna y Flora, Silvestre y Marina, 130 taxones y 6 poblaciones de la flora vascular del País Vasco," B.O.P.V n¹41, de 28 de Julio.

[103] "ORDER 3901, de 20 de Mayo de 2003, del Consejero de Ordenación del Territorio y Medio Ambiente, por la que se modifica el Catálogo Vasco de Especies Amenazadas de la Fauna y Flora, Silvestre y Marina," B.O.P.V n¹29, de 2 de Julio.

[104] “DECREE 151/2001, de 23 de Julio, por el que se crea el Catálogo de Especies Amenazadas de Canarias," B.O.C n97, de 1 de Agosto.

[105] "LAW 4/2010, de 4 de junio, del Catálogo Canario de Especies Protegidas," B.O.C n¹12, de 9 de Junio.

[106] "DECREE 120/2008, de 4 de Diciembre, por el que se regula el Catálogo Regional de Especies Amenazadas de Cantabria," B.O.C n²49, de 26 de Diciembre.

[107] “DECREE 33/1998, de 5 de Mayo, por el que se crea el Catálogo Regional de especies Amenazadas de Castilla-La Mancha," D.O.C.M n²2, de 15 de Mayo.

[108] “DECREE 200/2001, de 6 de noviembre, por el que se modifica el Catálogo Regional de Especies Amenazadas de Castilla-La Mancha," D.O.C.M n¹19, de 13 de Noviembre.

[109] "DECREE 63/2007, de 14 de Junio, por el que se crean el Catálogo de Flora Protegida de Castilla y León y la figura de protección denominada Microrreserva de Flora," B.O.C.yL $\mathrm{n}^{\circ} 119$, de 20 de Junio.

[110] "DECREE 172/2008, de 26 de Agosto, de creación del Catálogo de Flora amenazada de Cataluña," D.O.G.C n5204, de 28 de Agosto.

[111] "DECREE 70/2009, de 22 de Mayo, el Consell, por el que se crea y regula el Catálogo Valenciano de Especies de Flora Amenazadas y se regulan medidas adicionales de conservación," D.O.C.V nº621, de 26 de Mayo.

[112] "DECREE 37/2001, de 6 de marzo, por el que se regula el Catálogo Regional de Especies Amenazadas de Extremadura," D.O.E $n^{\circ} 30$, de 13 de Marzo.

[113] "DECREE 88/2007, de 19 de Abril, polo que se regula o Catálogo galego de especies ameazadas," D.O.G nº89, de 9 de Mayo.

[114] "DECREE 59/1998, de 9 de Octubre, por el que se crea y regula el Catálogo Regional de Especies Amenazadas de la Flora y Fauna Silvestre de La Rioja," B.O.L.R nº123, de 13 de Octubre.

[115] "DECREE 18/1992, de 26 de Marzo, por el que se aprueba el Catálogo Regional de Especies Amenazadas de Fauna y Flora Silvestres y se crea la categoría de árboles singulares," B.O.C.M $\mathrm{n}^{\circ} 85$, de 9 de Abril.
[116] “DECREE 50/2003, de 30 de Mayo, por el que se crea el Catálogo Regional de Flora Silvestre Protegida de la Región de Murcia y se dictan normas para el aprovechamiento de diversas especies forestales," B.O.M n'131, de 10 de Junio.

[117] "DECREE Foral 94/1997, de 7 de Abril, por el que se crea el Catálogo de la Flora Amenazada de Navarra y se adoptan medidas para la conservación de la flora silvestre catalogada," B.O.N.A nº47, de 18 de Abril.

[118] H. A. Pedersen, "Systematics and evolution of the Dactylorhiza romana/sambucina polyploid complex (Orchidaceae)," Botanical Journal of the Linnean Society, vol. 152, no. 4, pp. 405-434, 2006.

[119] C. Venhuis, P. Venhuis, and A. C. Ellis-Adam, "A new Tongueorchid (Orchidaceae) in Southwest Spain: serapias occidentalis," Anales del Jardin Botánico de Madrid, vol. 63, no. 2, pp. 131-143, 2006.

[120] IUCN, Categorías y criterios de la lista roja de la IUCN, vol. 3.1, Comisión de Supervivencia de especies de la IUCN, Gland, Suiza y Cambridge, Reino Unido, UK, 2001.

[121] Reinhard and Gölz, Ber.Schweiz. Bot. Ges, vol. 85, no. 4, p. 288, 1976.

[122] ProyectoOrquídea, http://proyectoorquidea-extremadura.blogspot.com/, 2010.

[123] Orquídeas Ibéricas, http://www.orquideasibericas.info, 2013. 


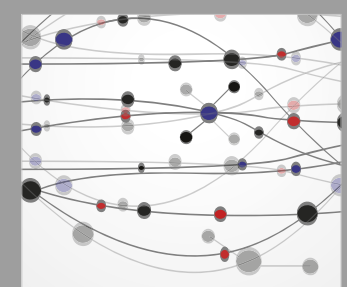

The Scientific World Journal
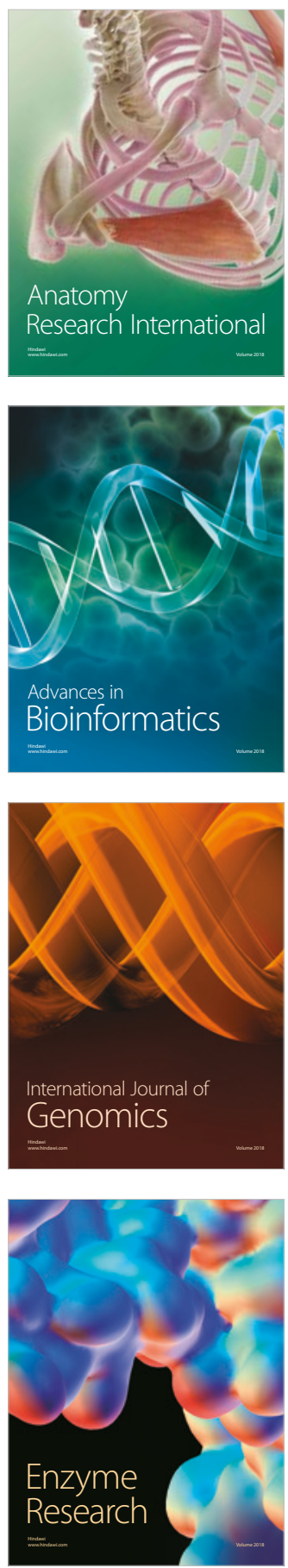
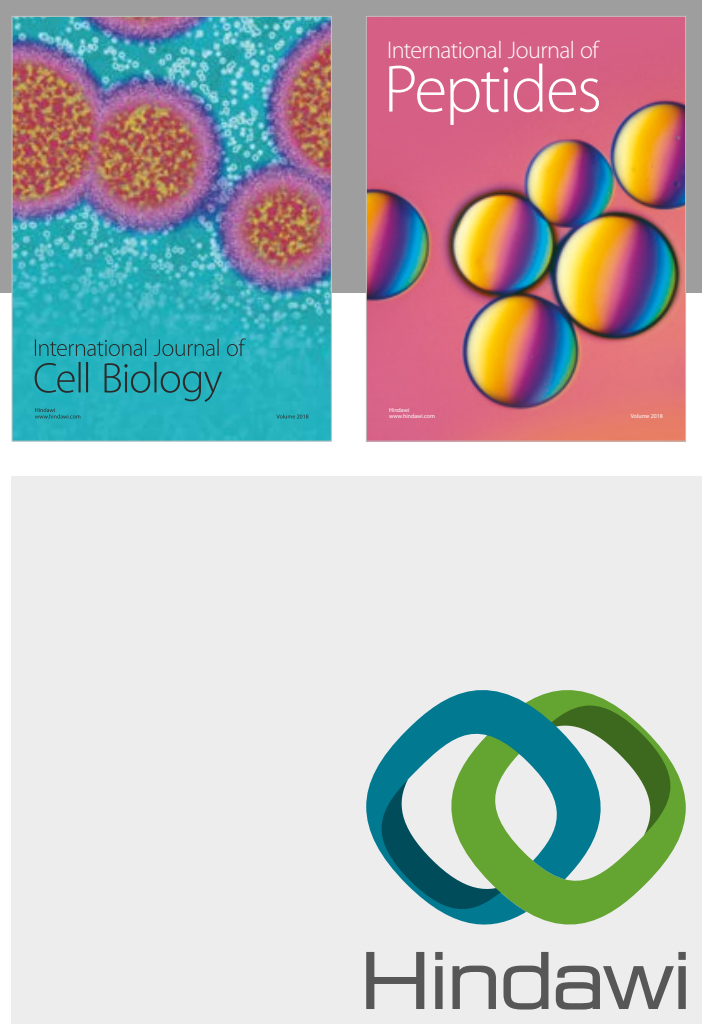

Submit your manuscripts at

www.hindawi.com
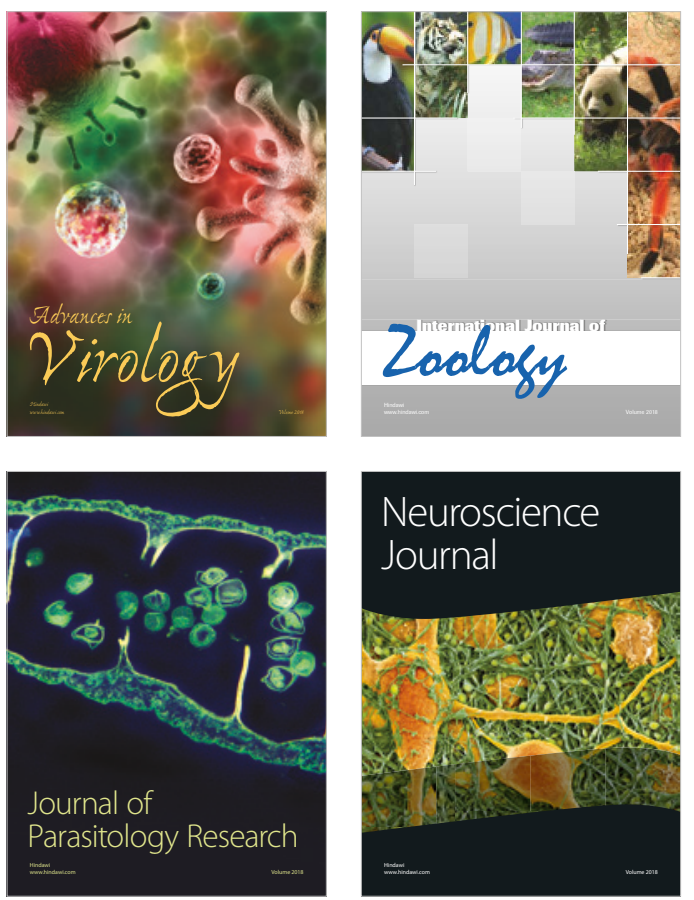
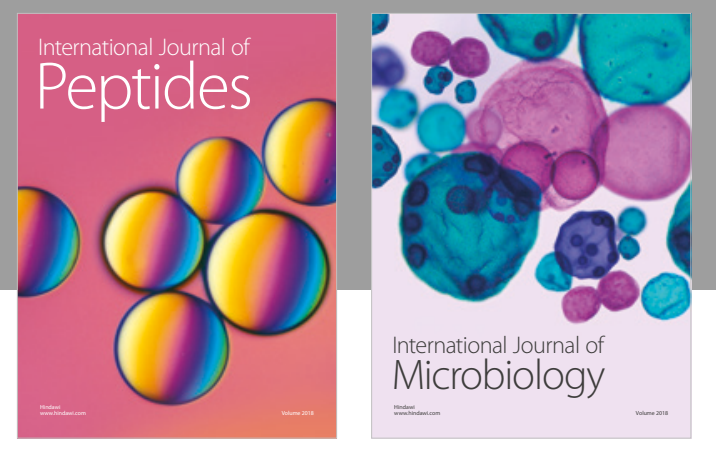

nternational Journal of Microbiology
Journal of
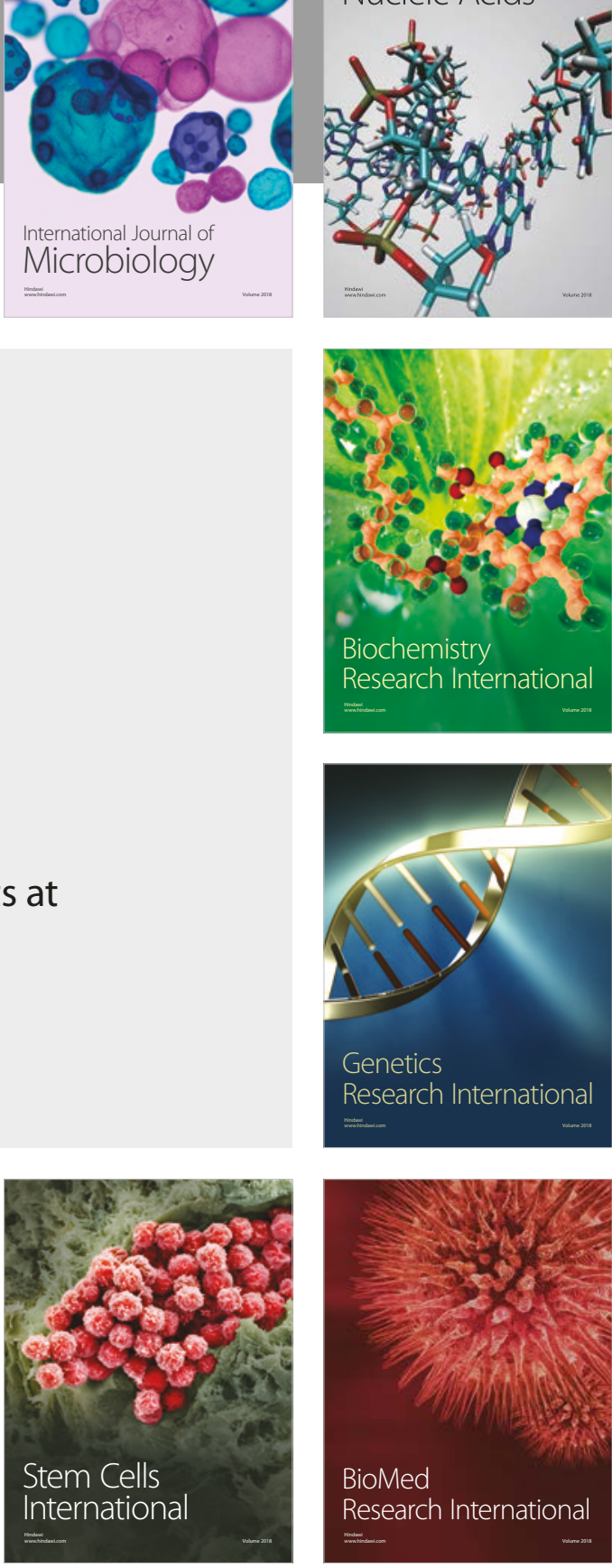
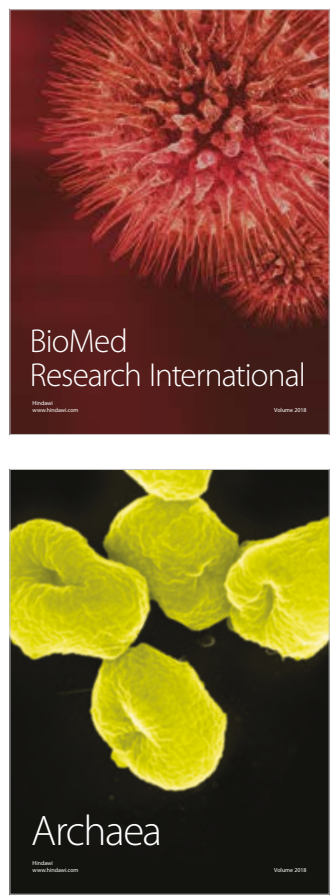